\title{
Mapping social conflicts in natural resources: a text mining study of extractive activities
}

\author{
Ramiro Albrieu and Gabriel Palazzo
}

\begin{abstract}
Applying text mining techniques, a methodology was developed to measure the number of social conflicts related to the exploitation of non-renewable natural resources. The study focuses on conflicts in four mining countries (Australia, Canada, Chile and Peru) between 2003 and 2016, based on more than 20,000 articles from the leading newspapers of each country. A statically significant correlation was found between the main index and mineral rents as a percentage of gross domestic product (GDP). However, the results should be interpreted with caution since endogeneity issues have not been addressed and the indices could be biased by various, country-specific factors. This study's main outcome is a database with different indices of soft conflicts related to the exploitation of non-renewables natural resources and its media coverage in Australia, Canada, Chile and Peru.
\end{abstract}

\section{Keywords}

Social conflict, natural resources, non-renewable resources, mining, statistical data, Australia, Canada, Chile, Peru

JEL classification

$\mathrm{J} 23, \mathrm{~J} 24, \mathrm{O} 33$

\section{Authors}

Ramiro Albrieu is an associate researcher in the Economics Department of the Center for the Study of State and Society (CEDES). Email: ralbrieu@cedes.org.

Gabriel Palazzo is a research assistant in the Economics Department of the Center for the Study of State and Society (CEDES). Email: gabrielmpalazzo@gmail.com. 


\section{Introduction}

The exploitation of underground natural resources is a controversial issue. On the one hand, it can boost government revenues and provide the economy with the necessary income for growth, what Hirschman (1977) called indirect linkages. On the other hand, there is a perception, both in the literature and among the general public, that the social costs of these exploitation activities are not given due consideration when governments (or companies) decide to deplete a given non-renewable natural resource. This is particularly true when it comes to the effects of current actions on the well-being of future generations, but also to their contemporary local effects.

The climate change agenda and, more specifically, the literature on green accounting and its main applications (such as the System of Environmental-Economic Accounting (SEEA) developed by the United Nations) seeks to address the issue of intergenerational equity (United Nations, n/d). The World Bank (2006 and 2011) estimates of adjusted net saving tackle the intergenerational problem by correcting standard accounting savings (the sum of present and future well-being) and measuring investments in human and physical capital, the depletion of natural resources, and environmental damage caused by carbon dioxide and other emissions. However, the issue of intragenerational equity has been harder to address.

This article seeks to contribute to the literature on the exploitation and depletion of natural resources by finding proxy measures for social conflicts at the national and local (or regional) levels. The main goal is to draw attention to conflicts related to the exploitation of natural resources that national institutions and the private sector must address. To that end, patterns of words related to social conflicts were identified in articles about the mining sector published in the leading newspapers of four countries that are major producers of minerals, namely Australia, Canada, Chile and Peru. The main contribution of this study has been the creation of a database to explore causal effects and correlation in an effort to ensure better conflict management in the future.

The advantage of these indices is that they are able to capture minor conflicts and to measure the intensity of different conflicts. But a major weakness is that they may contain biases as a result of the different degrees of lobbying by the extractive industries, government or other agents on the media. However, if the impact of lobbying remained stable over time, the indices in the country sample will only be biased at the country level. This could be easily resolved by using fixed-effect regression models. Problems arise if lobbying varied over time or was subject to temporal shocks. Nevertheless, even if there is some bias, it is still interesting to evaluate the media coverage of social conflicts related to natural resources.

This article is organized as follows. Section II contains a brief overview of the literature on text mining in economics and explains the methodology applied to measure social conflict. Section III presents the main results at the country level, addresses regional disparities within countries, and defines the different levels of violence in the conflict indices measured. Section IV contains the regression models used to evaluate the relationship between conflicts and a country's mineral income and overall economic performance. Lastly, the conclusions are set out in section V.

\section{Quantifying social conflicts in extractive industries}

\section{Literature review}

The methodology used in this study is rooted in text mining techniques. These techniques allow conclusions to be reached, foster computational research and detect statistical patterns by studying the words present in a text. 
Online newspapers contain vast amounts of qualitative information that can be processed using new software to obtain quantitative assessments for hard-to-quantify economic variables. Gupta and Lehal (2009) describe text mining as "the discovery by computer of new, previously unknown information, by automatically extracting information from different written resources" (p. 60).

The literature on the use of these techniques in economics has grown over time. Tetlock (2007) is one of the pioneers in this area, constructing a measure of media pessimism, mining the daily "Abreast of the Market" column in the Wall Street Journal. Using basic vector autoregressions (VARs), he finds that high values of media pessimism robustly predict downward pressure on market prices, followed by a reversion to fundamentals. Tetlock's findings suggest that measures of media content serve as a proxy for investor sentiment. By the same token, García (2013) constructs an index of market sentiment by counting the number of positive and negative words of two financial columns ("Financial Markets" and "Topics in Wall Street") from the New York Times, which were both published daily over the period 1905-2005. In accordance with Tetlock (2007), García finds that media content can predict trading volume. Using a parsimonious time-series model, García also finds that news content helps to predict daily stock returns, particularly during recessions. Aromí (2013) applies a similar methodology to evaluate how information flows from newspapers influenced the performance of the financial market in Argentina from October 1996 to December 2012. He carries out time-series regression models on stock returns, the determinants of which are media sentiment measures that he has constructed, the lags of these variables and the stock returns lags, among other control variables. Aromí finds evidence compatible with the presence of market participants who overreact to information flows. To obtain a quantitative index all these studies used a dictionary approach, counting positive and negative words to generate a numerical index.

Baker, Bloom and Davis (2013) use text mining techniques to construct an index that quantifies the uncertainty surrounding economic policy and its impact on investment demand in the context of the 2007-2009 economic recession in the United States. They built an economic policy uncertainty (EPU) index which sought to capture the prevailing uncertainty about tax, spending, regulatory and monetary policies. The EPU index is based on an automated text search for terms related to economic policy uncertainty in 10 leading newspapers published in the United States.

Social conflicts over natural resources have a much longer history than the text mining methodology used in this paper. Since the 1980s, the conventional view that natural resource endowments promote economic development has been called into question, with many contending that those very endowments are at the root of underdevelopment. Sachs and Warner (1995) attribute the lower growth exhibited by countries with a high share of commodity exports for the period 1970-1989 to the curse of natural resources. More recently, Brunnschweiler and Bulte (2009) state that there are no less than three different dimensions of the curse of natural resources: (i) slower economic growth; (ii) violent civil conflict; and (iii) undemocratic regimes.

Several reasons may link the exploitation of natural resources to social unrest and political conflicts. Possible hypotheses put forward by Sachs and Warner (1995) and Leite and Weidmann (1999) are that natural resource-rich countries exhibit higher inequality and social polarization because the ruling elite takes advantage of its political power to lobby for resources, fostering rent-seeking behaviour. Collier and Hoeffler (1998, 2004 and 2005) analyse different causes of civil wars and rebellions, among which an abundance of natural resources seems to have a considerable effect. Collier and Hoeffler (2004) contrast the hypothesis that rebellions may be explained by atypically severe grievances with the idea that they are caused by atypical opportunities for building a rebel organization. Their results support the opportunity hypothesis. They interpret the positive relationship between primary commodity exports and higher conflict risk as being due to the opportunities such commodities provide for extortion, making rebellion feasible and perhaps even attractive. 
Along a similar line, Nafziger and Auvinen (2002) and Sinnott, Nash and De la Torre (2010) suggest that conflicts could be arise because different social groups do not receive what they consider to be their fair share, indicating a predatory State, weak regulations and elites that leverage resources to extract rents rather than promote economic growth. Sinnott, Nash and De la Torre (2010) identify the social consequences of mining and oil exploitation, which have high potential to generate social tensions and conflicts, in many cases because of their adverse environmental impact and poor working conditions. In turn, the "Dutch Disease" theory and the Prebisch-Singer hypothesis offer explanations as to why the exploitation of natural resources and its impact on the economy can generate social unrest among certain segments of the population (Singer, 1950; Prebisch, 1950).

Brunnschweiler and Bulte (2009) argue that it is necessary to instrument the variables involved. The authors find that there is endogeneity between these variables and reverse causality, whereby peace reduces a country's dependence on natural resources and that it is not the dependency on commodity exports that creates social conflict, which runs contrary to the resource curse thesis; in fact, they find that an abundance of resources could have a positive impact on economic growth. Mehlum, Moene and Torvik (2006), like Brunnschweiler and Bulte (2009), Arezki and van der Ploeg (2007), Haber and Menaldo (2011), and Leite and Wiedmann (1999), claim that the quality of institutions determines whether natural resource abundance is a blessing or a curse. Meanwhile, Giordano, Giordano and Wolf (2005) and Evans (2010) posit that natural resource scarcity may increase the risk of future sociopolitical conflicts. Robinson, Torvik and Verdier (2006) built a political economy model to analyse the impact of natural resources on development. They propose a model where politicians permit the over extraction of natural resources and then engage in inefficient redistribution of the resulting revenues to try to influence elections. However, they conclude that in countries with institutions which limit the ability of politicians to use clientelism to bias elections, resource booms tend to raise national income.

At the time of writing, few studies have used text mining to examine the relationship between natural resource exploitation and sociopolitical conflicts. To our knowledge, the methodology adopted by UNDP/Fundación UNIR (2012) is the closest to ours since they also use media coverage to analyse conflicts. For that study of social conflict in Latin America, data were collected from 54 newspapers published in 17 Latin American countries from October 2009 to September 2010. The authors identify three different spheres of conflict: (i) social reproduction (which account for the largest share of conflicts in the period analysed and includes those related to work/wages, land and incomes); (ii) institutional conflicts (related to demands for practical improvements in the provision of public goods, administrative management and the legitimacy of public authorities); and (iii) cultural conflicts (related to ideological-political issues, public safety and the environment, among other things).

Another example in this field is Dube and Vargas (2013), who use newspaper articles to characterize violent civil conflicts in Colombia. They present evidence that a rise in the price of oil intensified violence in areas transporting and producing more oil, while a fall in the price of coffee increased violence in municipalities growing more coffee. The key difference between these activities is the labour intensity gap. On one hand, the fall in coffee prices reduces workers' wages and lowers the cost of recruiting workers into armed groups. This is called opportunity cost effect. On the other hand, the oil shock substantially increases local government revenue, encouraging paramilitary groups to move into oil areas to control these resources. This is called the rapacity effect. Unlike the present study, however, Dube and Vargas use a dataset from the Conflict Analysis Resource Center (CERAC) collected from newspaper articles, rather than constructing a new database using text mining technique.

Lastly, the empirical strategy used in this paper is borrowed from Palazzo (2017), who created social conflict indices related to the exploitation of a broad set of natural resources in Argentina over the period 1996-2014. This was a major contribution to the development of the methodology and procedure for verifying whether those indices reliably showed some stylized facts about civil conflicts related to agriculture, mining, oil, fishing and forestry activities in Argentina. 


\section{Empirical strategy used}

We have developed a methodology that measures the quantity of sociopolitical conflicts related to the exploitation of mineral resources, that might be applied to other natural resources (see Palazzo, 2017). A text mining bag-of-words model was used, which consisted of counting the number of hostile words in each article that referenced the extractive industries in a particular location and time period. The number of articles about conflicts serves as a proxy for the level of conflict at a particular point in time and in a particular place. We then used this information to create a set of indices (on, for example, the ratio of hostile words to total words per article) to capture the intensity of conflicts.

The majority of the literature on social conflicts examines civil wars where the number of dead people is the measure of intensity. Our index differs from those constructed by other authors, by offering a soft measure of conflict that takes into account strikes, lockouts, protest marches and political struggles. In addition, the conflicts are unequivocally related to the extractive industries because of the nature of the methodology.

The data was taken from Factiva (Dow Jones, 2020), a website that collects and stores a large number of newspapers from around the world and classifies the articles by industry and sector. We have chosen the areas of Mining/Quarrying and Primary Metals Industries, to ensure that each news article concerns the sector under analysis.

Ideally, more than one newspaper per country would have been used in order to avoid or smooth out media biases. However, despite the fact that Factiva covers a broad range of newspapers, not all of them are available for the whole period under consideration and the number of newspapers covered is not the same for all the countries analysed. This data restriction meant that the period of time and the number of newspapers used to build the indices had to be limited. If more than one newspaper per country had been used, then the time period of available data would have been reduced to less than three years. We therefore decided to use only one newspaper per country and thus extend the time frame covered by the database to 2003-2016. As noted above, this is the database's major weakness, as the indices might be biased as a result of the different degrees of lobbying by the extractive industries, governments or other agents on the media with regard to coverage of conflicts in each country.

However, if the impact of lobbying remained the same over time, the indices in the country sample will only be biased on the country level. This is not a real concern because the variation will be still informative of increases or decreases in conflict levels. Problems will arise if the intensity of the lobbying varied over time. In the event that pressure from lobbyists varies across the country but remains stable over time, it will limit the country-level analysis, but it can be easily resolved by applying a fixed-effects regression model. However, steps should be taken in the future in an effort to avoid or minimize this potential pitfall.

The newspapers with the largest circulation were used for each country analysed, namely El Mercurio for Chile, El Comercio for Peru, the Herald Sun for Australia and The Globe and Mail for Canada. Data were available from November 2002 for El Mercurio, October 2002 for El Comercio, July 1997 for the Herald Sun and December 1986 for The Globe and Mail. Since most newspapers carry articles referring to other countries, we deleted those articles that contained the name of other countries and did not mention the name of the country of interest. The time period covering 2003 to the first semester of 2016 was chosen in order to have a balanced panel of data.

The identification of conflicts was crucial to the process. In line with UNDP/Fundación UNIR (2012), this study adopts a classic definition of social conflict as a process of contentious interaction between social actors and institutions which mobilize with different levels of organization and act collectively in order to improve conditions, defend existing situations, or advance new alternative social projects. A social conflict arises when a social group, actor or movement (workers, entrepreneurs, campesinos, indigenous peoples, teachers, civic movements, students, trade unions, academics, etc.) expresses a collective malaise in a hostile manner through demands and violent tactics designed to exert pressure (strikes, marches, riots, demonstrations, occupations of facilities, etc.) against any public or private body (p. 283). 
Taking this definition, a dictionary-based approach was adopted to detect these patterns in the news articles. The hostile words category of the Harvard IV-4 dictionary ${ }^{1}$ was used, with 687 entries in English at the time of writing. These were then translated into Spanish and the database was expanded to a total of 1,326 words by adding Spanish synonyms for those hostile words (see annex A1).

To avoid any possible complications arising from the conjugation of verbs and the agreement of nouns and adjectives, the common word endings in English and Spanish were removed using $R$ software. Then, all words are rewritten in lower case letters, punctuation and accents were excluded, and common words in each language (like connectors) were deleted to avoid counting extra words that did not add any meaning and may be used more or less often in each language.

Lastly, the statistical program $\mathrm{R}$ allowed us to systematize this process to generate the indices for each country, which were then disaggregated by administrative area. Text mining techniques were subsequently carried out again; by checking to see if an article contained the name of the administrative area, the main cities and/or the mining sites in that area, the articles were categorized by region.

Three alternative indices were created that served as proxy variables for the number of social conflicts related to natural resources (Palazzo, $\mathrm{n} / \mathrm{d}$ ) and could be used for different purposes. They are:

- Conflict news: Let $C N_{i, t}$ be newspaper articles that include hostile words about the country or region $i$ at time $t$, thus the conflict news index for each country or region is $C N_{i}=\sum_{t} C N_{i, t}$ and the total conflict news index for each period $C N_{t}=\sum_{i} C N_{i, t}$. This index may have numerous biases because, for example, it does not control for whether an increase in the number of hostile words is solely attributable to that fact that more reports are published on the matter.

- Standardized conflict news: In accordance with Baker, Bloom and Davis (2013), let $T N_{i, t}$ be newspaper articles about the extractive industries in country or region $i$ published in period $t$, thus the standardized conflict news index is $S C N_{i, t}=C N_{i, t} / T N_{i, t}$.

- Conflict intensity: Based on García (2013) and Aromí (2013), the intensity of a conflict is measured at a specific point in time and space as the ratio of the number of hostile words to the total number of words inside the subset of conflict news. Let $C W_{i, t}$ be the number of hostile words found in the conflict news index and $T W_{i, t}$ the total number of words in those articles, thus conflict intensity in country or region $i$ during the period $t$ is $C I_{i, t}=C W_{i, t} / T W_{i, t}$.

\section{Social conflicts related to extractive activities}

\section{Country comparisons}

A total of 20,119 newspaper articles were collected about extractive industries from the four newspapers analysed covering the period between the first quarter of 2003 and the second quarter of 2016. Of these articles, $78 \%$ were classified as conflict news (see table 1), ${ }^{2}$ indicating that the public is generally pessimistic about extractive activities. This was to be expected given that our unit of analysis is newspaper articles.

When the data are disaggregated by country, some differences arise. First, the percentage of standardized conflict news $\left(S_{C N} N_{i, t}\right)$ is higher in the developed countries - around $92 \%$ for both Australia and Canada-, while in Chile and Peru it is between $63 \%$ and $66 \%$. With regard to conflict intensity, the values are higher for the developed countries, with the figure for Canada slightly higher than that for Australia.

These results are descriptive of the general findings of this paper and the database that we have constructed. However, they should not be interpreted as meaning that conflict levels are higher

\footnotetext{
1 See [online] http://www.wjh.harvard.edu/ inquirer/homecat.htm.

2 Our main indices, disaggregated by month and year, are freely available at https://sites.google.com/view/gabrielmpalazzo/ original-databases. Our codes in $\mathrm{R}$ format are available upon request.
} 
in Australia and Canada than in Chile and Peru. Firstly, since we are comparing indices created from different newspapers, a higher proportion of standardized conflict news or conflict intensity could be explained by the preferences or interests of different readerships as well as the different writing styles of the newspapers' journalists. In addition, the differences in levels among the countries analysed coincide with languages differences; we therefore cannot discount the fact that native speakers of the two languages may express facts and their opinions in a different manner. Lastly, as was noted above, the differences might be attributable to different biases in the media. These results should therefore be interpreted as indices composed of different constants and the analysis should focus on how behaviour changes over time and the responses following relevant shocks from exogenous variables.

Table 1

Australia, Canada, Chile and Peru: national patterns in social conflicts related to extractive activities, first quarter of 2003-second quarter of 2016

(Total number of articles and percentages)

\begin{tabular}{lcccc}
\hline Country & $\begin{array}{c}\text { Total number of articles } \\
\text { on extractive activities } \\
T N_{i, t}\end{array}$ & $\begin{array}{c}\text { Conflict news } \\
C N_{i, t}\end{array}$ & $\begin{array}{c}\text { Standardized conflict news } \\
\text { (standardized index) } \\
S C N_{i, t} \\
\text { (percentages) }\end{array}$ & $\begin{array}{c}\text { Conflict intensity } \\
C_{i, t} \\
\text { (percentages) }\end{array}$ \\
\hline Australia & 2709 & 2502 & 92.36 & 3.70 \\
\hline Canada & 6871 & 6349 & 92.40 & 4.53 \\
\hline Chile & 8095 & 5375 & 66.40 & 2.76 \\
\hline Peru & 2444 & 1543 & 63.13 & 2.89 \\
\hline Total & 20119 & 15769 & 78.37 & 3.81 \\
\hline
\end{tabular}

Source: Prepared by the authors, on the basis of articles obtained from El Mercurio, El Comercio, The Globe and Mail, and Herald Sun newspapers.

Turning to time patterns (see table 2), three different subperiods can be detected with regard to the conflict news index, $C N_{i, t}$. The first, extending roughly from 2003 to 2006, where social conflict appears to be increasing; a second where conflict steadily decreases (2007-2009); and a third (2010-2016) where it remains generally stable (despite two spikes in 2010 and 2014). However, the standardized index $S C N_{i, t}$, reveals a different picture: the trend was relatively stable during the period 2003-2007, reflecting that conflict news grew pari passu with total news, before jumping and stabilizing at higher levels through the period 2008-2013; lastly, it fluctuates over the 2014-2016 period, peaking in 2015.

Table 2

Australia, Canada, Chile and Peru: time patterns in social conflicts related to extractive activities, 2003-2016

(Total number of articles and percentages)

\begin{tabular}{lcccc}
\hline Year $t$ & $\begin{array}{c}\text { Total number of articles } \\
\text { on extractive activities } \\
T N_{i, t}\end{array}$ & $\begin{array}{c}\text { Conflict news } \\
C N_{i, t}\end{array}$ & $\begin{array}{c}\text { Standardized conflict news } \\
\text { (standardized index) } \\
\text { SCN }_{i, t} \text { ) } \\
\text { (percentages) }\end{array}$ & $\begin{array}{c}\text { Conflict intensity } \\
\text { CI }_{i, t} \\
\text { (percentages) }\end{array}$ \\
\hline 2003 & 822 & 695 & 84.55 & 4.02 \\
\hline 2004 & 1394 & 1049 & 75.25 & 3.42 \\
\hline 2005 & 1497 & 1091 & 72.88 & 3.20 \\
\hline 2006 & 2128 & 1637 & 76.93 & 3.62 \\
\hline 2007 & 1952 & 1270 & 65.06 & 3.63 \\
\hline 2008 & 953 & 664 & 69.67 & 3.47 \\
\hline 2010 & 774 & 529 & 68.35 & 4.02 \\
\hline 2011 & 938 & 755 & 80.49 & 4.42 \\
\hline 2012 & 670 & 495 & 73.88 & 4.03 \\
\hline 2013 & 669 & 541 & 80.87 & 4.03 \\
\hline 2015 & 732 & 535 & 73.09 & 3.98 \\
\hline 2016 & 908 & 502 & 55.29 & 3.75 \\
\hline
\end{tabular}

Source: Prepared by the authors, on the basis of articles obtained from El Mercurio, El Comercio, The Globe and Mail, and Herald Sun newspapers. 
With regard to the conflict intensity, the $C I_{i, t}$ index indicates a steady increase in the intensity of social conflicts related to extractive activities between 2003 and 2010, before starting to diminish, albeit slowly.

Lastly, figure 1 shows the country-specific evolution of social conflict over time. Regarding both the total news index $T N_{i, t}$ and the conflict news index $C N_{i, t}$, it is clear that they peaked during the 2004-2008 period. In turn, the standardized index reveals that the aforementioned country differences are present over the whole period under analysis. The indices for Chile and Peru are more volatile than those of Australia and Canada, and social conflict in Chile grew significantly over the last two years of the period under analysis. Two interesting points arise with regard to conflict intensity. Firstly, that the Peru index is more volatile than the others; meaning that, unlike the other countries, Peru is subject to "explosions" of intense conflicts. Secondly, the conflict intensity remained relatively low in Chile during the whole period. ${ }^{3}$

Figure 1

Australia, Canada, Chile and Peru: social conflicts related to extractive activities, 2003-2016

A. Total news

(total number of articles)

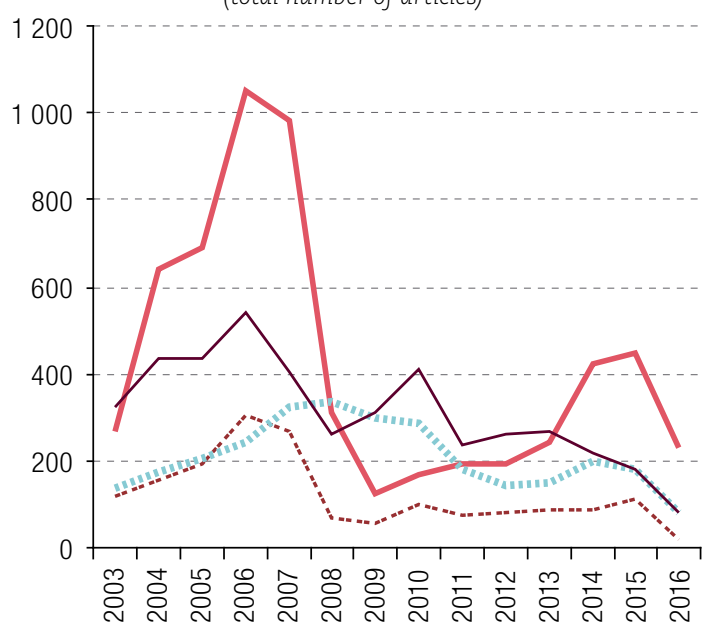

C. Standardized conflict news (percentages)

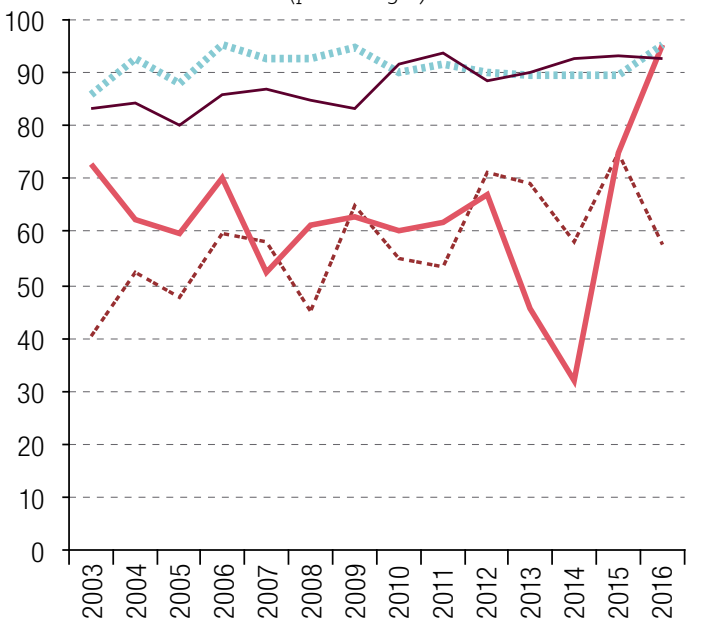

B. Conflict news (total number of articles)

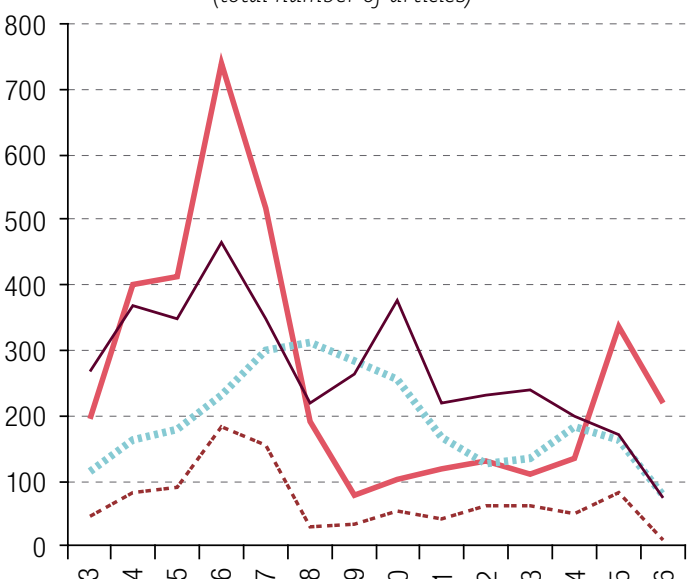

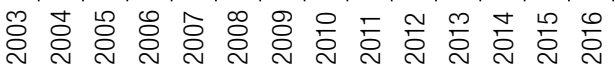

D. Conflict intensity (percentages)

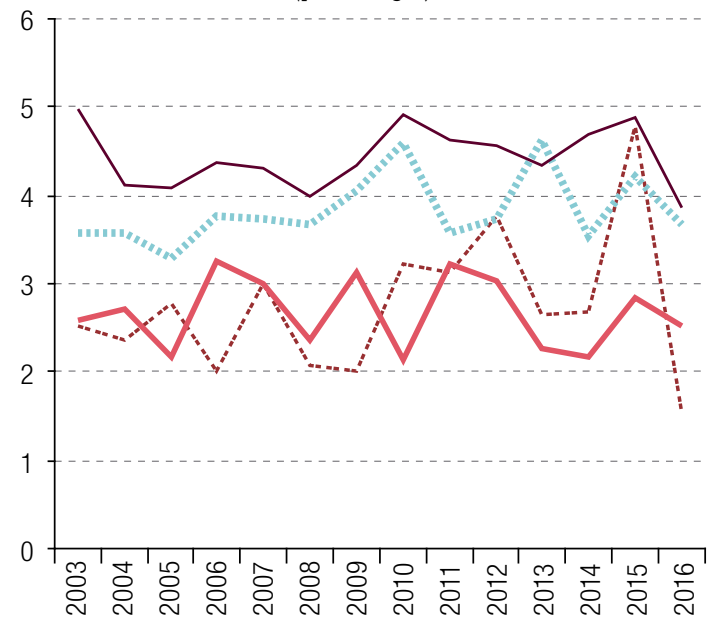
- Chile - Canada "n!n Australia --... Peru

Source: Prepared by the authors.

3 It should be borne in mind that conflicts can arise in a specific territory but companies from different countries might be involved. For example, Canadian companies could be involved in conflicts in Africa or Chile. The methodology used was unable to address these data challenges and if the news appears in the Canadian newspaper then it will be allocated as conflict news for that country. 
The main advantage of the text mining technique is that it allows a huge amount of unstructured data to be processed without qualitative analysis. However, it could be informative to match some of the peaks to important events. For example, in November 2010 there was peak in mining conflict news in Canada which coincided with the controversial attempt by the Australian firm BHP Billiton to acquire Potash Corp, which was blocked by the Canadian Prime Minister, Stephen Harper. This is reflected in figure 1 by a rise in conflict news during 2010 in Canada. Another example is a strike for higher wages in Chile in December 2005 by the employees of the Ferrocarril de Antofagasta a Bolivia (FCAB), a privately-owned mining railway from Antofagasta in northern Chile to Bolivia. Around that time there was also some controversy since the Chilean peso appreciated against the United States dollar and mining firms were complaining about the hit to their profits. Moreover, during the first months of 2006, some members of the opposition raised questions in parliament about the hiring of consultants and services carried out by the Coporación Nacional del Cobre de Chile (CODELCO), the Chilean State-owned copper mining company. All of these events coincide with a spike in the conflict news index for Chile in 2006.

These are some examples of the types of conflicts that the indices are capturing. However, we do not have an objective measure of conflicts to check the accuracy of the indices. It is not conclusive to try to check the accuracy of the indices against the newspaper articles, since they are the primary source of information for building the indices. Nevertheless, the indices are a first step towards documenting civil conflicts related to extractive activities in the future.

\section{Regional comparisons}

To disaggregate conflicts by administrative area, we used the text mining approach to categorize each article by state, territory, province, region or department to see whether it contained the name of that administrative area, the capital cities or the names of mining sites in those areas

As was expected, the administrative areas that accounted for a higher share of total news articles related to mining are those where extractive industries are present. Figure 2 shows the relationship between administrative areas' shares of national mining gross domestic product (GDP) around 2013 and 2014 and their share of total news articles on mining for each country.

The results reveal a clear correlation between both indices, particularly for Ontario (Canada), Western Australia (Australia) and region II, Antofagasta, (Chile), where the main producer regions have the highest number of news articles about mining. The number of articles drops as the mining sector becomes less important.

The correlation is weaker in Peru but remains high. Lima accounts for the highest share of news articles on mining but is ranked fifth in terms of extractive activity (7\%). Although it is not the main mining department (Cusco and Ancash are the most important), it is not unreasonable for mining news to be reported in the capital city, where parliament and national politicians are located. These results are in line with the findings of Palazzo (2017).

To obtain regional values for the standardized conflict index and conflict intensity index, regional maps of social conflicts related to the extractive industry were compiled. To analyse regional differences within each country, four distinct subgroups were considered: considerably above average, above average, below average and considerably below average. The two subgroups that are considerably above or below the average refer to instances where the index reaches higher (lower) values than the average value plus (minus) one standard deviation. The other two subgroups exhibit values above or below the average but within normal standards of deviation (see map 1). 
Figure 2

Australia, Canada, Chile and Peru: share of extractive activities and mining news articles, by administrative area, first quarter of 2003-second quarter of 2016

(Percentages)
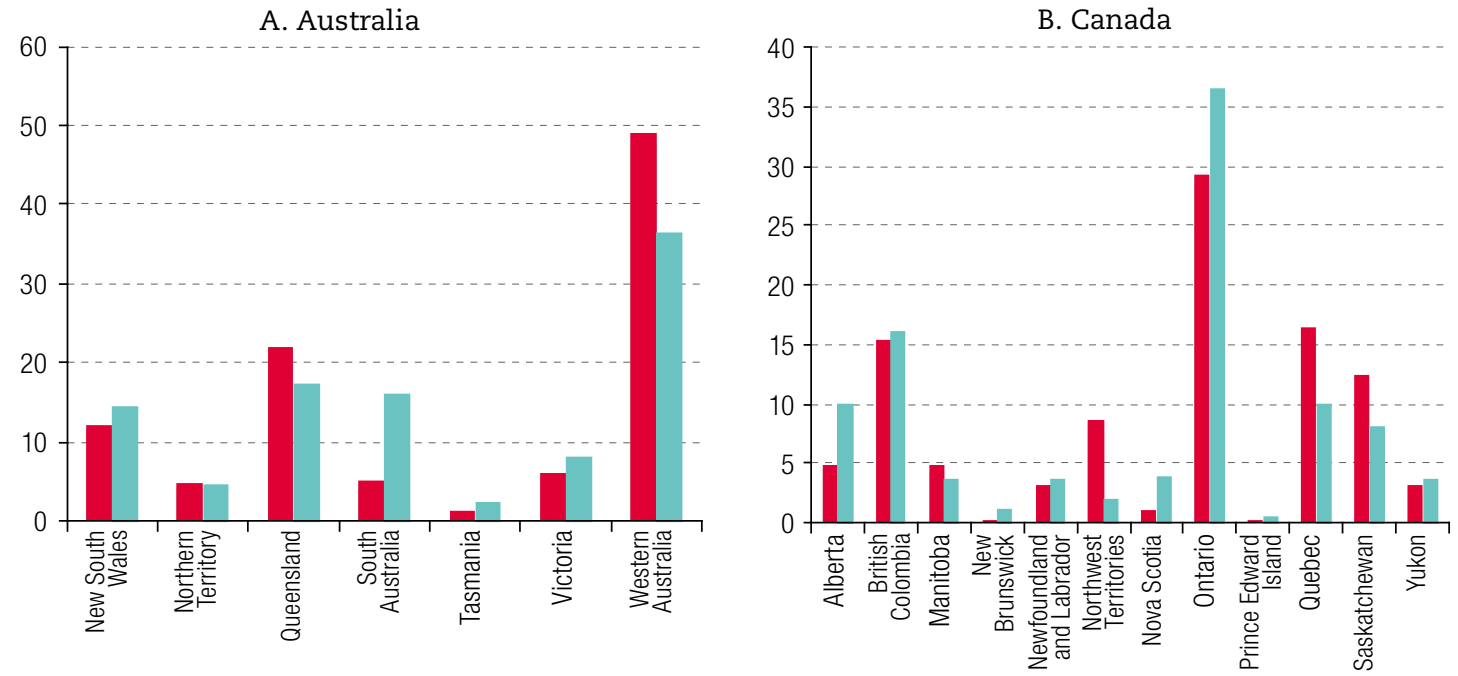

C. Chile

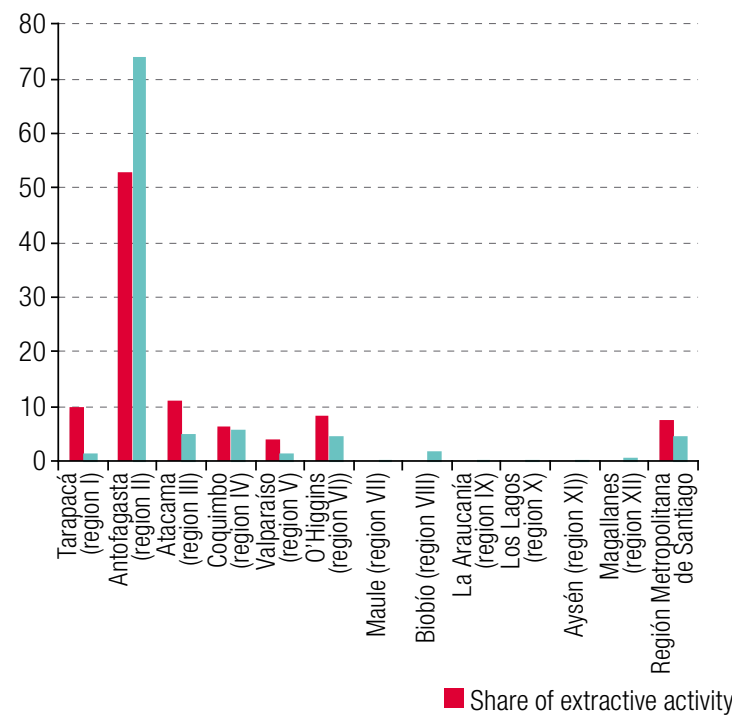

D. Peru

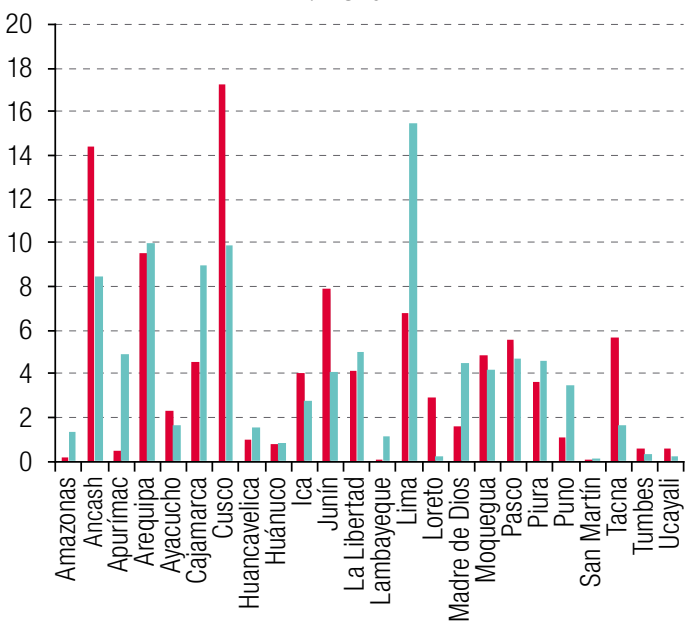

Share of total news

Source: Prepared by the authors.

Note: No data were available for the following administrative areas: Australian Capital Territory (Australia), Nunavut (Canada), Los Ríos (region XIV), Arica and Parinacota (region XV) and Nuble (region XVI) (Chile), and Callao (Peru). They are therefore not included in these indices.

Starting with the standardized conflict index, in Australia, Queensland has a particularly high level of conflict. For one thing, the proportion of negative news surpasses 95\% (92.3\% is the average for the country as a whole). Meanwhile, Western Australia and the Northern Territory have relatively low levels of conflict (about $90 \%$ of the news articles contain hostile words). The total variability, however, is relatively low (the coefficient of variation is 0.023 ). 
Map 1

Australia, Canada, Chile and Peru: standardized conflict index by administrative area, first quarter of 2003-second quarter of 2016

A. Australia

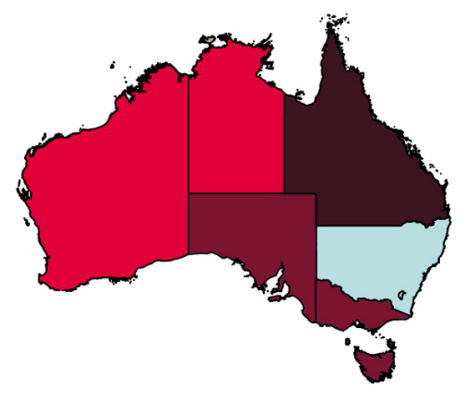

C. Chile

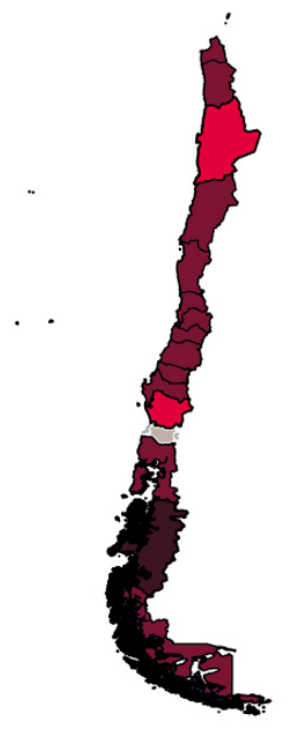

B. Canada

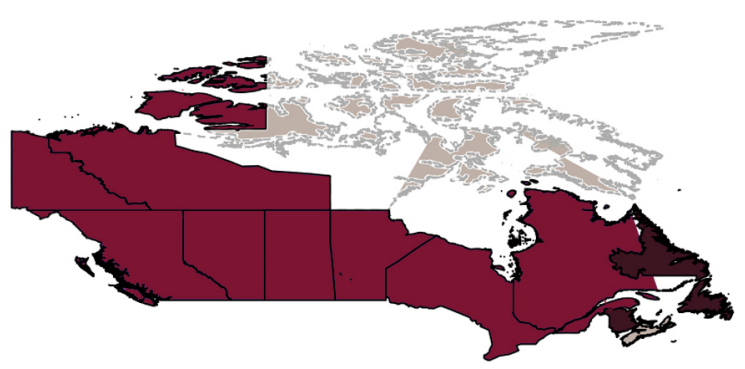

D. Peru

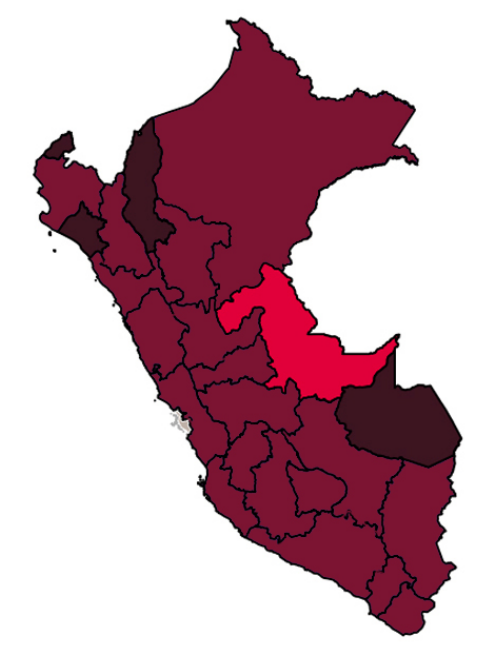

Considerably above average

Above average Below average No data available

Source: Prepared by the authors.

Note: No data were available for the following administrative areas: Australian Capital Territory (Australia), Nunavut (Canada), Los Ríos (region XIV), Arica and Parinacota (region XV) and Ñuble (region XVI) (Chile), and Callao (Peru). They are therefore not included in these indices.

In Canada, the conflict index is also close to 92\%. New Brunswick and Newfoundland, two eastern provinces, stand out for their high share of negative news, over 95\%, while Nova Scotia has the lowest (84.5\% of the news articles contain hostile words). This outlier means that the total variability index for Canada is higher than that of Australia.

Chile has a lower level of conflict: its index is close to $80 \%$. The differences among the regions are more marked than in the previous cases, and consequently the coefficient of variation is higher $(0.12)$. The index exceeds $85 \%$ in some regions, while in others it is less than $70 \%$. Three regions that are not traditionally mining areas are in the first group, namely Aysén (region XI), Los Lagos (region X) and Magallanes (region XII). It is interesting to note that one of Chile's major mining areas, Antofagasta 
(region II), is - together with La Araucanía (region IX) - among the regions with the lowest levels of conflict (with just $61 \%$ of negative news articles).

Lastly, in Peru, the contrast among the different departments is even starker: some have a conflict index of less than $50 \%$, while for others it is nearly $90 \%$ (the coefficient of variation rises to 0.23 ). Three departments are particularly prone to conflict, specifically Amazonas, Madre de Dios and Tumbes, while Ucayali has the lowest level of conflict associated with extractive activity.

With regard to the conflict intensity index (see map 2), Victoria is the Australian state with the greatest conflict intensity; almost one in every 20 words in the relevant news articles is hostile. Meanwhile, Queensland, which has the highest level of conflict, recorded a lower level of conflict intensity, as was expected. At the other end of the spectrum, the Northern Territory had the lowest level of conflict and the lowest intensity ratio (one in every 30 words is a hostile word).

\section{Map 2}

Australia, Canada, Chile and Peru: conflict intensity index by administrative area, first quarter of 2003-second quarter of 2016

A. Australia

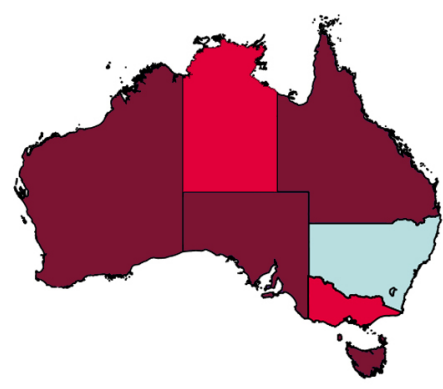

C. Chile

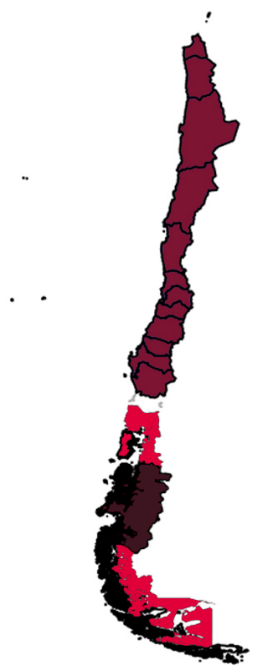

- Above average
B. Canada

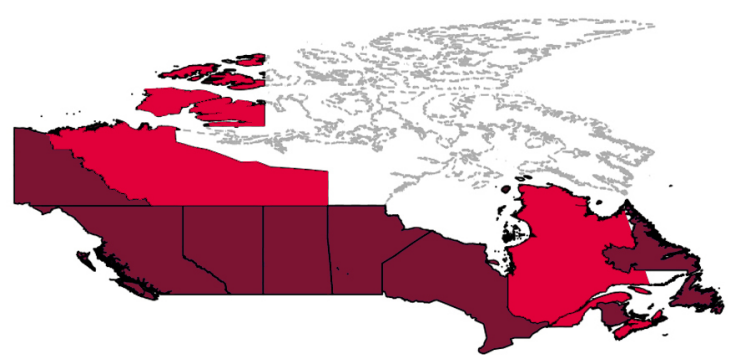

D. Peru

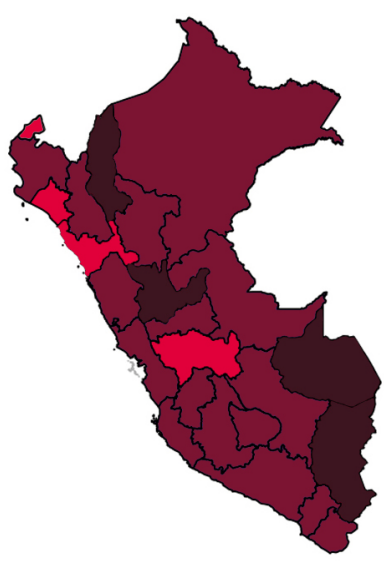

Considerably above average Below average

Considerably below average No data available

Source: Prepared by the authors.

Note: No data were available for the following administrative areas: Australian Capital Territory (Australia), Nunavut (Canada), Los Ríos (region XIV), Arica and Parinacota (region XV) and Nuble (region XVI) (Chile), and Callao (Peru). They are therefore not included in these indices. 
The conflict intensity is much more homogeneous across the administrative areas of Canada: the variation coefficient is 0.045 and the percentage of hostile words varies between $4.0 \%$ and $4.7 \%$. Two areas stand out for their low conflict intensity: the Northwest Territories and Nova Scotia.

Regional disparities in the intensity of social conflicts are more pronounced in the developing countries. In Chile, for example, regions such as Aysén (region XI), Maule (VII) and O'Higgins (VI) recorded high levels of conflict intensity, while Magallanes (XII) and Los Lagos $(X)$ recorded the lowest. As a result of these differences, the variation coefficient is 0.20 .

The disparities in Peru are even greater. In four departments (Madre de Dios, Huánuco, Puno and Amazonas) the conflict intensity was high, with at least one in every 30 words related to conflict, while it was low in four others (Junín, La Libertad, Lambayeque and Tumbes). The variation coefficient for Peru is the highest of the four countries under analysis, at 0.25 .

\section{Intensity of conflict violence}

It may sound counterintuitive that the results of the indices of social conflicts related to extractive activities are higher in developed countries than in developing ones. Although possible methodological reasons for this have already been identified and the best way to use the indices has been explained, some possible explanations for the different types of conflicts that the indices are capturing in the country sample are set out below. One testable hypothesis is that the developed country indices are capturing softer conflicts than those for developing countries. The indices are built in such a way that, for example, the word "death" has the same weight as "disagreement". Thus, conflict intensity should be redefined in a manner that will allow us to discriminate between violent and non-violent conflicts.

To that end we developed an violent conflict index based on the share of hostile words in a given period and country that can be classified as violent, that is $V C_{i, t}=V W_{i, t} / C W_{i, t}$, where $V C_{i, t}$ is the index and $V W_{i, t}$ is the sum of violent words (the subgroup of hostile words that are violent can be found in annex A1). $C W_{i, t}$ is the sum of hostile words defined above. The results are presented in figure 3.

Figure 3

Australia, Canada, Chile and Peru: violent conflicts related to extractive activity, 2003-2016

(Percentages)

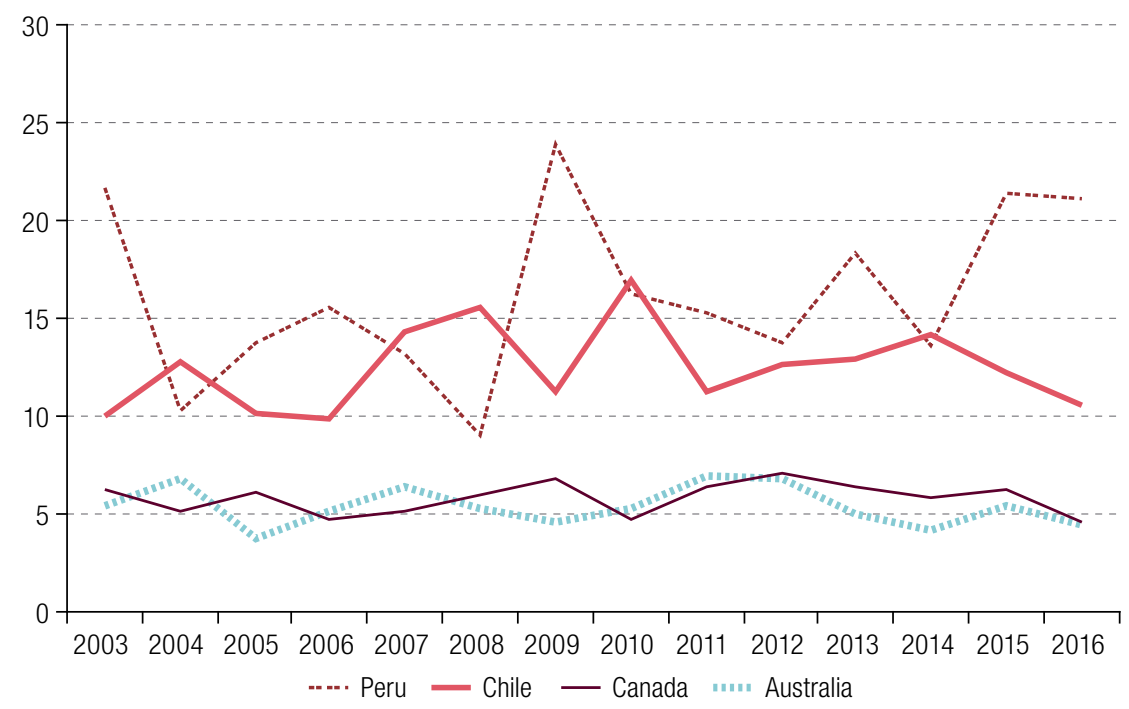

Source: Prepared by the authors. 
As was expected, violent conflicts related to extractive activities were more common in the developing countries. In Australia and Canada, the share of violent conflicts in total hostile conflicts was consistently around $5 \%$. In the case of Chile, the results yield an average around $11 \%$ for the whole 2003-2016 period, while in Peru the average is around 15\%. Our main hypothesis is that these findings might be related to weaker governance or the fact that fewer mechanisms are available to resolve and address social demands in developing countries which leads to surges of violent conflict. Moreover, inequality is greater and polarization more pronounced in developing countries, causing civil conflicts to be more violent than those in developed countries.

It should also be borne in mind that some soft conflicts in developing countries might receive less media coverage owing to the greater lobbying power of elites, including the owners of mining deposits, to soften unfavourable news (for more in-depth analysis of this hypothesis, see Nafziger and Auvinen, 2002, and Sinnott, Nash and De la Torre, 2010). However, further analysis is needed to understand this difference between developed and developing countries, as well as a bigger sample of countries.

\section{Some stylized facts from the database}

\section{Common drivers or country-specific trends?}

Further analysis of the correlation between the conflict indices in our sample produces some interesting results. Table 3 contains the correlation matrix, using the annual frequency of the different conflict indices.

Table 3

Australia, Canada, Chile and Peru: correlation matrix

\begin{tabular}{|c|c|c|c|c|c|c|c|c|}
\hline \multirow[b]{2}{*}{ Country } & \multicolumn{4}{|c|}{ A. Conflict news } & \multicolumn{4}{|c|}{$\begin{array}{l}\text { B. Standardized conflict news } \\
\text { (standardized index) }\end{array}$} \\
\hline & Chile & Peru & Canada & Australia & Chile & Peru & Canada & Australia \\
\hline Chile & 1 & & & & 1 & & & \\
\hline Peru & 0.9337 & 1 & & & -0.023 & 1 & & \\
\hline Canada & 0.6876 & 0.6976 & 1 & & -0.2708 & 0.514 & 1 & \\
\hline \multirow[t]{2}{*}{ Australia } & 0.1821 & 0.1894 & 0.2793 & 1 & 0.0544 & 0.1963 & -0.056 & 1 \\
\hline & \multicolumn{4}{|c|}{ C. Conflict intensity } & \multicolumn{4}{|c|}{ D. Violent conflict intensity } \\
\hline Country & Chile & Peru & Canada & Australia & Chile & Peru & Canada & Australia \\
\hline Chile & 1 & & & & 1 & & & \\
\hline Peru & 0.0559 & 1 & & & -0.4069 & 1 & & \\
\hline Canada & 0.0165 & 0.5365 & 1 & & -0.3009 & 0.3782 & 1 & \\
\hline Australia & -0.1647 & 0.2451 & 0.3076 & 1 & 0.0878 & -0.2599 & -0.024 & 1 \\
\hline
\end{tabular}

Source: Prepared by the authors.

The correlation analysis, using annual data, shows that, without any control, conflicts related to extractive activities in the sample countries do not covariate. Only the conflict news for Chile, Peru and Canada show some positive and significant correlation. Australia does not correlate in a positive and statistically significant way with any of them. These results were confirmed using quarterly data and by performing a factor analysis (see table 4). ${ }^{4}$

\footnotetext{
4 Eight monthly observations were excluded from the conflict intensity index for Chile because their values were five times the standard deviation above the mean. These extreme values were only present in Chile and could have introduced bias into the correlation matrix analysis.
} 
Table 4

Australia, Canada, Chile and Peru: factor loadings ${ }^{a}$ and unique variances

\begin{tabular}{|c|c|c|c|c|c|c|}
\hline \multirow[b]{2}{*}{ Country } & \multicolumn{3}{|c|}{ A. Conflict news } & \multicolumn{3}{|c|}{$\begin{array}{l}\text { B. Standardized conflict news } \\
\text { (standardized index) }\end{array}$} \\
\hline & Factor 1 & Factor 2 & Uniqueness & Factor 1 & Factor 2 & Uniqueness \\
\hline Chile & 0.8047 & -0.0213 & 0.352 & -0.2342 & 0.3098 & 0.8491 \\
\hline Peru & 0.7634 & 0.0028 & 0.4172 & 0.2368 & 0.3054 & 0.8506 \\
\hline Canada & 0.565 & 0.0043 & 0.6807 & 0.4341 & -0.0043 & 0.8115 \\
\hline \multirow[t]{2}{*}{ Australia } & 0.1375 & 0.0916 & 0.9727 & 0.0658 & 0.0323 & 0.9946 \\
\hline & \multicolumn{3}{|c|}{ C. Conflict intensity } & \multicolumn{3}{|c|}{ D. Violent conflict intensity } \\
\hline Country & Factor 1 & Factor 2 & Uniqueness & Factor 1 & Factor 2 & Uniqueness \\
\hline Chile & 0.5141 & -0.096 & 0.7265 & -0.098 & 0.1821 & 0.9572 \\
\hline Peru & 0.505 & 0.0926 & 0.7364 & 0.28 & -0.1119 & 0.9091 \\
\hline Canada & 0.2574 & 0.0478 & 0.9315 & 0.3582 & 0.1113 & 0.8593 \\
\hline Australia & -0.0343 & 0.2837 & 0.9183 & -0.4298 & -0.0217 & 0.8148 \\
\hline
\end{tabular}

Source: Prepared by the authors.

a The factor loadings represent both how the variables are weighted for each factor and also the correlation between the variables and the factor.

Uniqueness shows the proportion of common variance of the variable not associated with the factors. The conflict news uniqueness figure is high for all the countries, but particularly Australia. The uniqueness figures are also very high for the standardized conflict news, conflict intensity and violent conflict intensity, averaging $0.876,0.828$ and 0.885 , respectively. These results may indicate that conflicts related to extractive activities arise because of local political and economic situations and that different countries manage common shocks in very different ways depending on their institutional frameworks, industries and general social structures. Figure 4 depicts the main factor of the indices and a commodity metals price index from the International Financial Statistics (IFS) database of the International Monetary Fund (IMF).

There are no evident conclusions to be drawn from figure 4 and it should be borne in mind that the uniqueness of each index is very high. However, figure 4 does indicate that the conflict intensity and violent conflict intensity indices (figures $4 \mathrm{C}$ and $4 \mathrm{D}$ ) are not related to fluctuations in the commodity metal prices index. Therefore, no econometric analysis was carried out for these indices.

With regard to the evolution of conflict news (figure 4A), there is an uptick in both metal prices and conflict news until 2007, but the trends diverged thereafter as commodity metal prices soared in 2008. One possible explanation for this divergence might be that the media outlets in the countries of our sample were focused on the international financial crisis. Another reason could be that the number of total conflicts related to extractive activities became more country specific after that crisis.

If the first explanation is correct, this issue may be rectified using the standardized conflict news index, the purpose of which is to correct the total number of conflict news articles by dividing them by the total number of news articles related to extractive activities. The main factor of the standardized conflict news index (figure 4B) follows an upward trend for the whole time period analysed. The positive relationship between both series might be spurious if both series are I(1).

An augmented Dickey-Fuller test was therefore performed. The null hypothesis is that the variable contains a unit root, and the alternative is that the variable was generated by a stationary process. Since both series show a unit root process, ${ }^{5}$ but the first difference is stationary, we tested for a cointegration relationship using the Engle-Granger methodology. ${ }^{6}$

\footnotetext{
5 The number of lags was selected using the Akaike information criterion (AIC).

6 See table A2.1 in annex A2 for augmented Dickey-Fuller tests on variables and residuals. This test was performed on the residuals to check for cointegration relationship. The correct critical value for each test is reported.
} 
Figure 4

Australia, Canada, Chile and Peru: commodity metal prices a and main factor loading

\section{A. Conflict news}

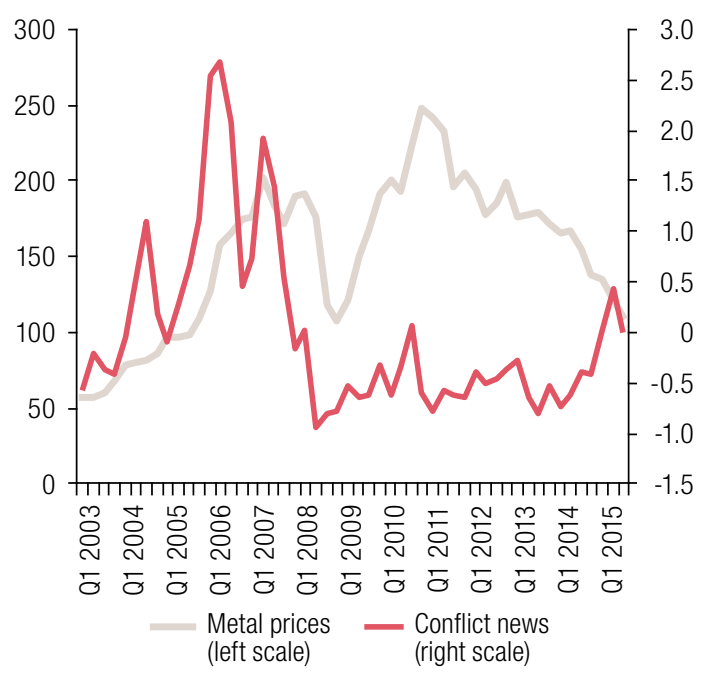

C. Conflict intensity

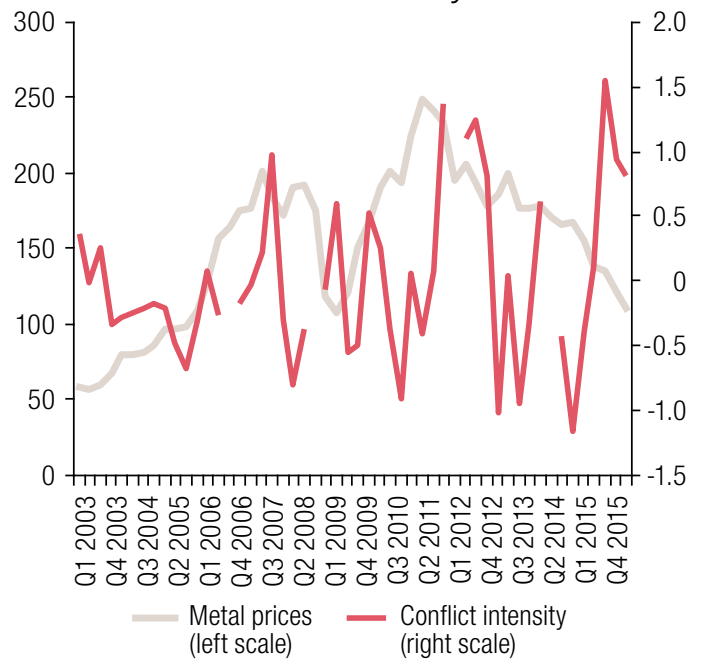

B. Standardized conflict news (standardized index)

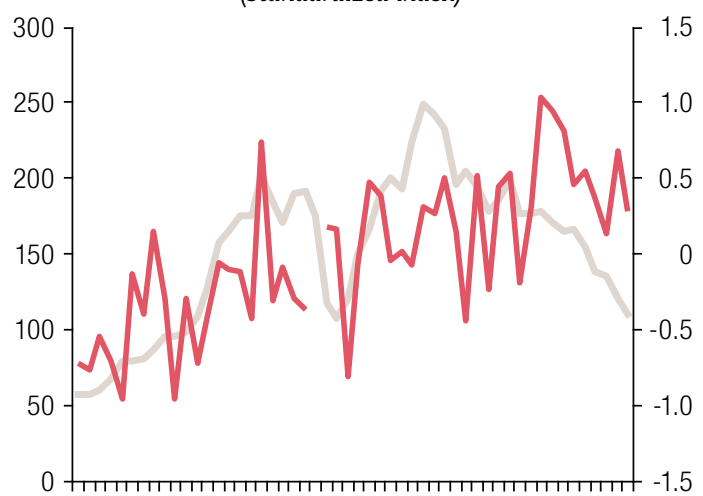

客苍 б $\bar{\sigma} \bar{\sigma} \bar{\sigma} \bar{\delta} \bar{\sigma} \delta \bar{\sigma} \delta \bar{\sigma} \delta$

Metal prices $\quad$ Standardized conflict news (left scale) (rights scale)

D. Violent conflict intensity

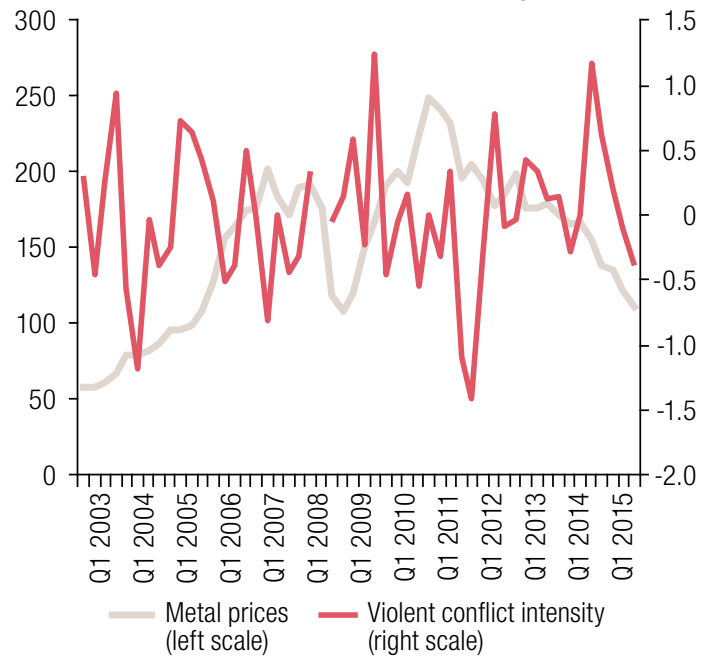

Source: by the authors, on the basis of International Monetary Fund (IMF), "International Financial Statistics (IFS)", 2020 [online database] https://data.imf.org/?sk=4C514D48-B6BA-49ED-8AB9-52B0C1A0179B\&sld=1409151240976.

a Commodity metals price index, $2005=100$, includes copper, aluminium, iron ore, tin, nickel, zinc, lead and uranium price indices.

Using a different numbers of lags as suggested by the likelihood-ratio (1 lag), Schwarz Bayesian information criterion (SBIC) (1 lag), Akaike information criterion (AIC) (3 lags), final prediction error (FPE) (3 lags) and Hannan-Quinn information criterion (HQIC) (2 lags) tests, we cannot reject the null hypothesis of no cointegration. The null hypothesis of no cointegration is only rejected when we select zero lags, but this is not suggested by any lag selection criteria. We then performed a vector autoregression (VAR) analysis of the differences among these variables. Since the countries analysed are major producers of metals, conflict trends common to all countries might also cause some variation in prices, owing to higher or lower production. A VAR model was estimated, using one lag (as suggested by the all different tests performed) without imposing any restriction. The following VAR(1) model was used: 


$$
\begin{gathered}
y_{1, t}=c_{1}+a_{1,1} y_{1, t-1}+a_{1,2} y_{2, t-1}+e_{1, t} \\
y_{2, t}=c_{1}+a_{2,1} y_{1, t-1}+a_{2,2} y_{2, t-1}+e_{1, t}
\end{gathered}
$$

where, $y_{1, t}$ is the first difference of the IFS commodity metal price index and $y_{2, t}$ is the first difference of the first loading factor of the standardized conflict news index $\left(S C N_{i, t}\right)$ (which is called $F 1_{S C_{i, t}}$ in table A2.2). Figure 5 shows the impulse response function (see table A2.2 in annex A2 for additional results).

Figure 5

Australia, Canada, Chile and Peru: impulse response function for commodity metal prices and main factor loading

A. Impulse response for standardized conflict news (standardized index)

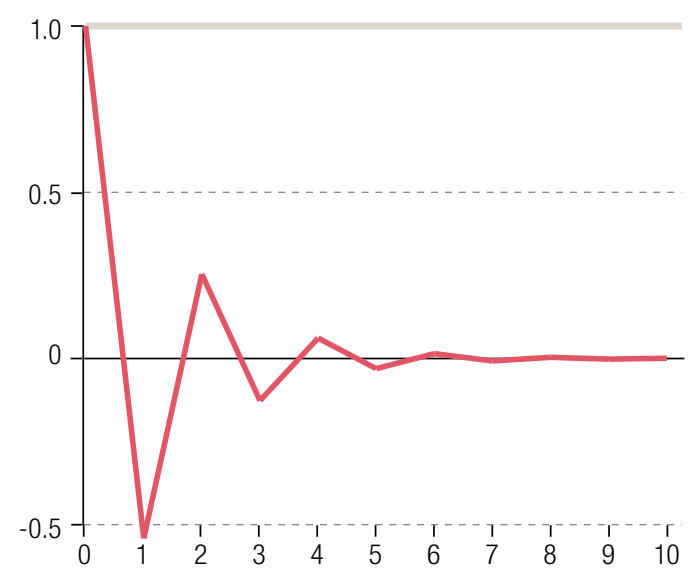

C. Impulse response of commodity metal prices index to standardized conflict news

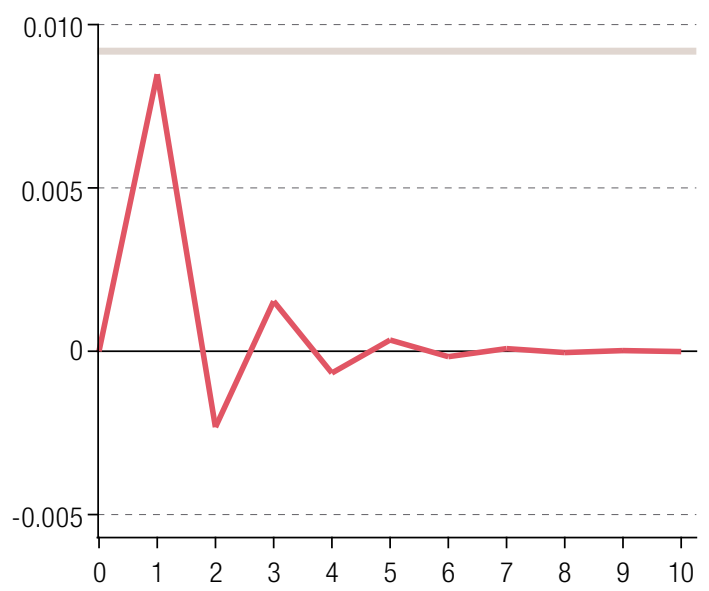

B. Impulse response of standardized conflict news to commodity metal prices index

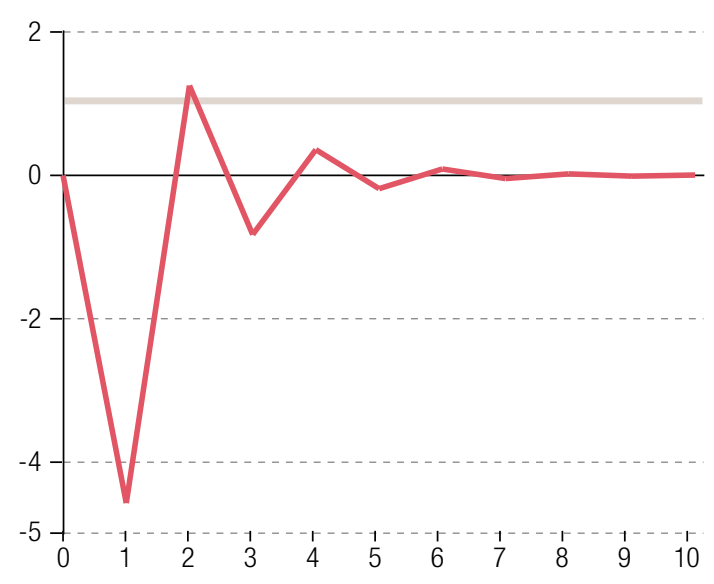

D. Impulse response for commodity metal prices index

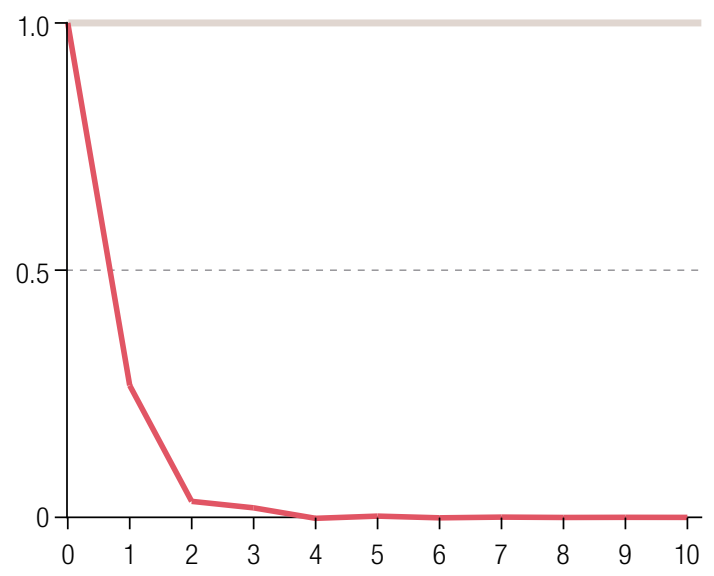

Source: Prepared by the authors.

Note: Graphs by iffname, impulse variable and response variable.

Figure $5 \mathrm{C}$ shows that a structural innovation in commodity metal prices predicts an increase in the standardized conflict index for the next quarter. This is not precisely estimated and if a Cholesky decomposition (ordering the commodity metal prices index first) is imposed the coefficient does not differ from 0 at normal significant levels, but still keeps the sign. This is an interesting prediction from a simple VAR model and may be a fruitful line for research in the future. It is also in line with the findings of Dube and Vargas (2013) regarding oil price shocks in Colombia. 


\section{Panel regressions}

This section contains deeper analysis of the relationship between conflicts, prices, mineral rents and general economic performance, using our panel database and correlating our indices to commodity metal prices, mineral rents as a percentage of GDP and per capita GDP (at constant 2010 United States dollars). The last two variables are taken from the World Bank Development Indicators database (World Bank, 2019). Annual data are used as the time pattern of our main potential determinants is annual.

The analysis is performed on the standardized conflict news $\left(S C N_{i, t}\right)$, conflict intensity $\left(C I_{i, t}\right)$, violent news as a percentage of conflict news and violent conflict intensity $\left(V C_{i, t}\right)$ indices. All regression models use country fixed-effects and year fixed-effects estimators. ${ }^{7}$ Our preferred regression model is the following:

$$
\ln \left(S C N_{i, t}\right)=\beta_{0}+\beta_{1} \ln \left(M R_{i, t}\right)+\beta_{2} \ln \left(G D P_{i, t}\right)+f_{i}+f_{t}+\epsilon_{j, t}
$$

where $M R_{i, t}$ is mineral rents as a percentage of GDP of country $i$ in year $t$; $G D P_{i, t}$ is the GDP of each country for each year; and $f_{i}$ and $f_{t}$ are time and country fixed-effects. However, we also tested replacing $M R_{i, t}$ with the commodity metal price index, and the level of GDP with the GDP growth rate. All our regressions should be interpreted with caution since reverse causality has not been properly taken into account in our analysis. However, the type of conflict does not seem as important a factor in causing a fall in production that affects commodity prices. The main results are presented in table 5.

Table 5

Year and country fixed-effects regressions of the standardized conflict news index

\begin{tabular}{|c|c|c|c|c|c|c|}
\hline Variables & $\begin{array}{c}1 \\
\text { In } \\
\text { (standardized } \\
\text { conflict news } \\
\text { (scn) index) }\end{array}$ & $\begin{array}{l}2 \\
\ln \\
\left(s c \_ \text {index }\right)\end{array}$ & $\begin{array}{l}3 \\
\ln \\
\text { (sc_index) }\end{array}$ & $\begin{array}{c}4 \\
\ln \\
\text { (sc_index) }\end{array}$ & $\begin{array}{c}5 \\
\ln \\
\left(s c \_ \text {index }\right)\end{array}$ & $\begin{array}{c}6 \\
\ln \\
\text { (sc_index) }\end{array}$ \\
\hline \multirow[t]{2}{*}{$\begin{array}{l}\text { In } \\
\text { (mineral rents } \\
\text { percentage } \\
\text { of GDP) }\end{array}$} & $0.222^{\star \star \star}$ & $0.214^{\star \star \star}$ & $0.226^{\star \star \star}$ & & & \\
\hline & (0.0709) & $(0.0725)$ & (0.0751) & & & \\
\hline \multirow[t]{2}{*}{$\begin{array}{l}\text { In } \\
\text { (metal_prices_index) }\end{array}$} & & & & 0.0559 & -0.00492 & 0.0449 \\
\hline & & & & $(0.0789)$ & $(0.0972)$ & $(0.0814)$ \\
\hline \multirow[t]{2}{*}{$\begin{array}{l}\text { In } \\
\text { (per capita GDP } \\
\text { - constant } 2010 \\
\text { United States dollars) }\end{array}$} & & 0.212 & & & 0.368 & \\
\hline & & $(0.317)$ & & & $(0.346)$ & \\
\hline \multirow[t]{2}{*}{$\begin{array}{l}\text { First difference In } \\
\text { (per capita GDP } \\
\text { - constant } 2010 \\
\text { United States dollars) }\end{array}$} & & & -0.385 & & & 1.224 \\
\hline & & & $(1.844)$ & & & (1.958) \\
\hline \multirow[t]{2}{*}{ Constant } & $-0.372^{\star \star \star}$ & -2.433 & $-0.364^{* *}$ & -0.620 & -3.946 & -0.600 \\
\hline & (0.0668) & (3.085) & $(0.0785)$ & $(0.380)$ & $(3.146)$ & $(0.385)$ \\
\hline Observations & 52 & 52 & 52 & 52 & 52 & 52 \\
\hline R-squared & 0.412 & 0.420 & 0.413 & 0.248 & 0.272 & 0.256 \\
\hline $\begin{array}{l}\text { Country and } \\
\text { year effects }\end{array}$ & Yes & Yes & Yes & Yes & Yes & Yes \\
\hline Number of countries & 4 & 4 & 4 & 4 & 4 & 4 \\
\hline
\end{tabular}

Source: Prepared by the authors.

Note: Coefficient significant at ${ }^{\star \star \star} p<0.01,{ }^{\star \star} p<0.05,{ }^{*} p<0.1$. Robust standard errors shown in parentheses.

\footnotetext{
7 Visual inspection of the standardized conflict news $\left(\mathrm{SCN}_{\mathrm{i}, t}\right)$ index may reveal that those series are not I(1). However, we performed Im-Pesaran-Shin test in Stata using AIC-selected lag, which led us to reject, with a p-value of 0.0185, the null hypothesis that all the panels contain a unit root.
} 
We find a positive and significant covariance between mineral rents as a percentage of GDP and the standardized conflict news index. This variable is stable and keeps its sign and significance even when per capita GDP or the first difference of per capita GDP is included, indicating that this variable is the relevant determinant, not the commodity metal price index, which is not significant when it is included alone or with the per capita GDP or the first difference of per capita GDP. Mineral rents as a percentage of GDP might be more accurate as it varies by country, while the commodity metal price index is the same for all the countries analysed.

One possible interpretation of our results is that higher mineral rents cause more conflicts to break out because different agents try to appropriate a higher percentage of those rents. These agents could be the government, domestic firms, foreign firms or workers. This is in line with the literature on the aforementioned resources curse (such as Brunnschweiler and Bulte, 2009), as well as with Dube and Vargas (2013) findings with regard to the "rapacity effect". Palazzo (2017) also arrives at a similar conclusion with regard to agricultural goods in Argentina.

Analysis of the index of violent news articles as ratio of total conflict news articles does not reveal any clear relationship between this variable and the commodity metal price index, mineral rents as a percentage of GDP and per capita GDP (see table A2.3). Additionally, our attempts to identify determinants for conflict intensity and violent conflict intensity were not successful. Lastly, we ran the same regression model, adding and changing some independent variables, but none of them were statistically significant. ${ }^{8}$

All these results should be treated with caution because our sample is small and endogeneity issues were not properly addressed. However, the correlation between the standardized conflict news index and mineral rents is interesting as it is in line with the literature on the resources curse. These results reinforce our previous findings, whereby the common factor of the standardized conflict news index $\left(S C N_{i, t}\right)$ seems to be predicted by a rise in commodity metal prices.

\section{Conclusions}

This paper examines the incidence and intensity of social conflicts related to extractive activities in four mining countries by applying text mining techniques to articles from the leading newspapers in each country for the period 2003-2016. The main outcome of this analysis is different measures of conflicts and conflict intensity that are available for further research.

It should be borne in mind that the country-specific differences identified could arise because of media biases, differences in expressions and ways to communicate news depending on the language used, and the different preferences or interests of the different newspapers' readerships which influence how journalists write their articles, among other things. Identifying these biases is a first step in trying to understand and measure civil conflicts related to extractive activities. Despite these potential biases, the major findings are as follows.

Firstly, we identified differences among Canada, Australia, Chile and Peru, as well as by year for each country. In the developed countries the level of conflict news was stable and consistently higher than that recorded in developing countries. In the latter, the media coverage of extractive activities tended to be more favourable, but some conflicts did arise during the period under consideration.

Secondly, we computed differences between the two groups of countries. With regard to the developed countries, the level of conflict news in Canada followed an upward trend (although it started

\footnotetext{
8 For example, we tested to see if the political cycle affected civil conflicts related to extractive activities. The political cycle variable was created by defining a dummy equal to 1 if a general election was held in the country in a particular year. If the election was held before the first quarter, the previous year was defined as the election year. Results are available upon request.
} 
from a lower level), and the intensity of conflict in Canada was higher than in Australia. In the developing countries, both the level and the intensity of social conflict in Peru increased, while in Chile there was no clear trend, even though it was notable for the fact that conflict intensity was low and stable. When social conflicts were categorized as violent or non-violent, we found a bias in developing countries towards violent conflicts.

Thirdly, analysis of social conflicts related to extractive activities produced some interesting results when disaggregated by subnational administrative area. We found that the number of news articles obtained using the text mining technique is correlated to the economic importance of extractive industries in a particular area. In addition, the average level of conflict in the developed countries for the period as a whole was fairly homogeneous across the subnational administrative areas, while the disparities were profound in the developing countries. The conflict intensity is also quite homogeneous in the developed countries and heterogeneous in the developing countries, especially in Peru.

Fourthly, we explored the extent to which national conflicts were interrelated. A common factor analysis was performed, which indicated that conflict levels are determined by the particular situation in each country. However, a positive common factor is related to the general index of commodity metal prices. Therefore, higher metal prices might be a predictor of a higher level of conflicts.

Lastly, this finding was tested by performing panel data regressions. A positive relationship was found between the standardized conflict news index and mineral rents as a percentage of GDP. This result is line with the rapacity effect identified by Dube and Vargas (2013) and the literature on the resources curse. However, our results should be taken with caution since our sample is small and we do not address endogeneity issues properly.

\section{Bibliography}

Arezki, R. and F. van der Ploeg (2007), "Can the natural resource curse be turned into a blessing? The role of trade policies and institutions", IMF Working Paper, No. 07/55, Washington, D.C., International Monetary Fund (IMF).

Aromí, J. (2013), "Media news and the stock market: evidence for Argentina" [online] https://docplayer. net/56643583-Media-news-and-the-stock-market-evidence-for-argentina.html.

Baker, S., N. Bloom and S. Davis (2013), "Measuring economic policy uncertainty", Chicago Booth Research Paper, No. 13-02, January.

Brunnschweiler, C. and E. Bulte (2009), "Natural resources and violent conflict: resource abundance, dependence, and the onset of civil wars", Oxford Economic Papers, vol. 61, No. 4, October.

Collier, P. and A. Hoeffler (2005), "Resource rents, governance, and conflict", The Journal of Conflict Resolution, vol. 49, No. 4, August.

(2004), "Greed and grievance in civil war", Oxford Economic Papers, vol. 56, No. 4.

(1998), "On economic causes of civil war", Oxford Economic Papers, No. 50.

Dow Jones (2020), "Factiva" [online] https://professional.dowjones.com/factiva/.

Dube, O. and J. Vargas (2013), "Commodity price shocks and civil conflict: evidence from Colombia", The Review of Economic Studies, vol. 80, No. 4, October.

Evans, A. (2010), "Resource scarcity, climate change and the risk of violent conflict", World Development Report 2011 Background Papers, No. 62050, Washington, D.C., World Bank, September.

García, D. (2013), "Sentiment during recessions", The Journal of Finance, vol. 68, No. 3, June.

Giordano, M., M. Giordano and A. Wolf (2005), "International resource conflict and mitigation", Journal of Peace Research, vol. 42, No. 1, January.

Gupta, V. and G. Lehal (2009), "A survey of text mining techniques and applications", Journal of Emerging Technologies in Web Intelligence, vol. 1, No. 1, August.

Haber, S. and V. Menaldo (2011), "Do natural resources fuel authoritarianism? A reappraisal of the resource curse", American Political Science Review, vol. 105, No. 1, February. 
Hirschman, A. (1977), "A generalized linkage approach to development, with special reference to staples", Essays on Economic Development and Cultural Change: in Honor of Bert F. Hoselitz, M. Nash (ed.), Chicago, The University of Chicago Press.

Humphreys, M. (2005), "Natural resources, conflict, and conflict resolution: uncovering the mechanisms", The Journal of Conflict Resolution, vol. 49, No. 4, August.

Leite, C. and J. Weidmann (1999), "Does mother nature corrupt? Natural resources, corruption, and economic growth”, IMF Working Paper, No. 99/85, Washington, D.C., International Monetary Fund (IMF), July.

Mehlum, H., K. Moene and R. Torvik (2006), "Cursed by resources or institutions?", The World Economy, vol. 29, No. 8, August.

Nafziger, E. and J. Auvinen (2002), "Economic development, inequality, war, and State violence", World Development, vol. 30, No. 2, February.

Palazzo, G. (2017), "Minería de datos, conflictos sociales y explotación de recursos naturales: un aporte metodológico", Compendium: Cuadernos de Economía y Administración, vol. 4, No. 7.

$(\mathrm{n} / \mathrm{d})$, "Original databases: conflicts and natural resources" [online database] https://sites.google.com/ view/gabrielmpalazzo/original-databases.

Prebisch, R. (1950), The economic development of Latin America and its principal problems (E/CN.12/89/ Rev.1), Santiago, Economic Commission for Latin America and the Caribbean (ECLAC).

Robinson, J., R. Torvik and T. Verdier (2006), "Political foundations of the resource curse", Journal of Development Economics, vol. 79, No. 2.

Sachs, J. and A. Warner (1995), "Natural resource abundance and economic growth", NBER Working Paper, No. 5398, Cambridge, National Bureau of Economic Research (NBER), December.

Singer, H. (1950), "U.S. foreign investment in underdeveloped areas: the distribution of gains between investing and borrowing countries", The American Economic Review, vol. 40, No. 2, May.

Sinnott, E., J. Nash and A. de la Torre (2010), Natural resources in Latin America and the Caribbean: beyond booms and busts?, Washington, D.C., World Bank.

Tetlock, P. (2007), "Giving content to investor sentiment: the role of media in the stock market", The Journal of Finance, vol. 62, No. 3, June.

UNDP (United Nations Development Programme)/Fundación UNIR (2012), "La protesta social en América Latina", Cuaderno de Prospectiva Política, No. 1, Buenos Aires, Siglo XXI.

United Nations (2014), System of Environmental-Economic Accounting 2012: Experimental Ecosystem Accounting (ST/ESASSTAT/Ser.F/112), New York. (n/d), "System of Environmental-Economic Accounting" [online] https://seea.un.org.

World Bank (2019), "World Development Indicators" [online database] https://databank.worldbank.org/ source/world-development-indicators.

(2011), The Changing Wealth of Nations: Measuring Sustainable Development in the New Millennium, Washington, D.C.

(2006), Where Is the Wealth of Nations? Measuring Capital for the 21st Century, Washington, D.C. 


\section{Annex A1}

\section{Hostile and violent words used for the text mining exercise}

Hostile words in English: abhor, abolish, abrasive, abscond, absentee, abuse, accost, accursed, accusation, accuse, acrimonious, acrimony, admonish, adversary, afflict, aggravate, aggravation, aggression, aggressive, aggressiveness, aggressor, aggrieve, agitator, alienate, allegation, altercation, ambush, anarchist, anarchy, anger, angry, anguish, animosity, annihilate, annihilation, annoy, annoyance, antagonism, antagonist, antagonistic, antagonize, argue, argument, arm, armed, arrest, arrow, assail, assailant, assassin, assassinate, assault, attack, attacker, austere, avenge, aversion, avert, avoid, avoidance, bandit, banish, barbarian, barbarous, bastard, battle, battlefield, beastly, beat, behead, belie, belittle, belligerent, belt, bereave, berserk, besiege, betray, betrayal, beware, bit, bitchy, bite, bitter, blame, blind, block, bloodshed, bloodthirsty, blurt, bomb, bombard, bombardment, bother, bout, boycott, brandish, brawl, breach, break, bristle, broke, brusque, brutality, brute, brutish, bug, bullet, burglar, burglary, butchery, callous, cannibal, cannon, capture, cataclysm, caught, censure, challenge, charge, chase, chastise, cheat, chide, chip, choke, clash, collide, collision, combat, combatant, compel, compete, competition, competitive, competitor, complain, complaint, compulsion, conceal, conceit, condemn, condemnation, condescending, condescension, conflict, confront, confrontation, conspiracy, constrain, contaminate, contamination, contempt, contemptible, contemptuous, contend, contest, contradict, convict, corruption, coup, cranky, crass, criminal, cripple, critic, criticize, crooked, crop, cross, cruel, cruelty, crush, crushing, curse, curt, cut, cynical, dagger, damage, damn, damnable, damned, deadlock, deadly, deceit, deceitful, deceive, deception, deceptive, defeat, defensive, defiance, defiant, defile, defy, degrade, demean, demolish, demon, demoralize, denial, denounce, deny, deplore, depose, deprive, deride, derision, derogatory, desert, despise, destroy, destruction, destructive, deterrent, detest, devastate, devastation, devil, devilish, devious, diabolic, diabolical, disagree, disagreeable, disagreement, disapprove, disavow, disavowal, disbelief, discord, discordant, discourage, discredit, discrepant, discrimination, disgust, dislike, dismiss, disobedience, disobedient, displeasure, dispose, disputable, dispute, disrupt, disruption, dissatisfied, dissent, dissention, distort, distrust, disturb, disturbance, ditch, divorce, drag, dump, egotistical, endanger, enemy, enforce, engulf, enrage, entanglement, epithet, escape, exception, exclude, exclusion, excommunication, execute, execution, exile, expel, exploit, fail, fallout, ferocious, ferocity, feud, fiend, fierce, fight, fighter, fire, fist, fled, floor, foe, fool, force, foreboding, fought, frighten, frown, frustrate, fun, furious, fury, germ, goddamn, grab, grapple, grenade, grudge, grumble, guerrilla, gun, gunmen, hamper, hang, harass, harassment, harm, harsh, hassle, hate, hater, hatred, haunt, heartless, hedge, heinous, hidden, hide, hinder, hindrance, hit, horrify, horror, hostile, hostility, humiliate, hunt, hunter, hurt, hustle, hustler, impair, impatience, impede, impediment, implicate, indictment, indignation, infect, infection, infiltration, inflame, infringement, infuriate, inhibit, inhibition, inhumane, injunction, injurious, injury, insolence, insolent, interfere, interference, interrupt, interruption, intrusion, irk, irritable, irritation, jagged, jail, jeer, jeopardize, jerk, kick, kidnap, kill, killer, knife, knock, laid, lawless, liar, lie, limit, liquidate, liquidation, litigant, litigation, lying, mad, malice, malicious, malignant, mangle, manslaughter, marksman, massacre, merciless, misbehave, mislead, missile, mob, molest, monster, monstrous, murder, murderous, mutter, nag, nasty, naughty, needle, negate, neglect, nigger, nightmare, obliterate, obnoxious, obstinate, obstruct, offend, offender, offensive, ominous, opponent, oppose, opposition, oppress, oppression, ostracize, oust, outlaw, outrage, pan, parasite, pass, penalty, penetrate, penetration, persecute, persecution, pinch, pistol, plague, plight, poisonous, pollute, posse, prejudice, pretend, pretence, prosecution, protest, provocation, provoke, prowl, punch, punish, push, quarrel, quarrelsome, quibble, rage, raid, raise, ravage, reactive, rebel, rebellion, rebellious, rebuff, rebuke, rebut, recalcitrant, refusal, refuse, reject, rejection, renounce, renunciation, repel, reproach, repulse, resent, resentful, resentment, resist, resistance, restrain, restrict, retaliate, retard, revenge, revolt, 
revolution, revolutionary, rid, ridicule, rifle, rip, rival, rivalry, robber, robbery, rogue, ruffian, ruinous, rumple, rupture, ruthless, ruthlessness, sabotage, sarcasm, sarcastic, savage, scandalous, scare, scared, scold, scorch, scorn, scornful, scoundrel, scowl, scuffle, seethe, segregation, sever, shadow, shaft, shatter, shock, shoot, shot, shove, shred, shrew, shrug, shudder, shun, shut, sick, siege, sinister, skirmish, slam, slander, slanderer, slanderous, slap, slash, slaughter, slayer, sleazy, slight, sly, smack, smash, smear, snarl, snatch, spank, spear, spite, spiteful, split, spoil, stab, stall, stamp, startle, steal, stern, stifle, sting, stole, stolen, stone, stop, storm, stormy, strangle, strife, strike, stringent, strip, struck, struggle, stubborn, stubbornly, stubbornness, stun, subdue, subversion, subvert, sunder, suppress, suppression, suspect, suspicion, suspicious, sword, taboo, taint, tamper, tantrum, taunt, tear, tease, temper, tempest, tense, terrorism, terrorize, theft, thief, thorny, thrash, threat, threaten, thwart, tire, tired, TNT, torment, tough, traitor, trample, trap, treacherous, treachery, treason, treasonous, trick, trigger, turbulent, ultimatum, undermine, unfair, unjust, unjustified, unleash, unruly, unsafe, untruth, unwilling, unwillingness, uprising, upset, usurp, vengeance, venom, venomous, vicious, victim, vie, villain, violate, violation, violence, violent, wait, walk, war, warlike, warrior, weapon, weed, wench, whack, whine, whip, wicked, wickedness, wily, witch, witchcraft, withheld, withhold, withstand, worry, wound, wrath, wreck, wrestle, wrong.

Violent words in English: aggressive, aggressiveness, ambush, arm, armed, assault, attack, beat, belt, bloodthirsty, bomb, brutality, bullet, butchery, crush, crushing, deadly, fire, guerrilla, gun, gunmen, kill, killer, monster, monstrous, murder, rebel, rebellion, slash, slayer, violence, violent, warrior, whip.

Hostile words in Spanish: abatir, abdicación, abdicar, abofetear, abolición, abolir, abominación, abominado, abominar, aborrecer, aborrecido, aborrecimiento, aborrezco, abrumar, abuchear, abucheo, abusar, abusivo, abuso, abyecto, acéfalo, acérrimamente, acérrimo, aciago, acobardar, acogotar, acorralamiento, acorralar, acosamiento, acribillar, acritud, acuchillar, acusación, adulterino, aflicción, afligido, afligir, agitación, agitador, agobiar, agobio, agolpamiento, agraviante, agraviar, agravio, agredir, agresión, agresividad, agresivo, agresor, ahogamiento, ahogar, ahogo, ahorcamiento, ahorcar, ahuyentar, ajusticiar, ajusticiamiento, alabarda, alboroto, alegación, alegato, alevosía, alienar, altercado, alzamiento, alzarse, embaucador, amedrentar, amenaza, amenazador, amenazar, ametralladora, ametrallar, amilanar, amohinado, amonestar, amotinador, amotinarse, amputar, anarquía, anárquico, anarquista, anatema, angustia, angustiado, animadversión, animosidad, aniquilación, aniquilamiento, aniquilar, anormalidad, antagónica, antagonismo, antagonista, antihigiénico, anticristo, apedrear, apercibir, apesadumbrado, apesadumbrar, aporrear, aprehender, apremio, apresamiento, apresar, aprieto, aprisionamiento, aprisionar, apuntar, apuñalar, arma, armamento, armas, arpía, arrebatar, arredrar, arremeter, arremetida, arrestar, arresto, arrinconar, arrogancia, arrogante, artero, artimaña, asaltado, asaltador, asaltante, asaltar, asalto, asco, asechada, asechanza, asechar, asediar, asesinar, asesinato, asesino, asfixia, asfixiar, asolación, asolar, asustar, atacante, atacar, ataque, atemorizar, atentado, atentar, aterrador, aterrar, aterrarse, aterrorizar, atizo, atormentado, atormentar, atosigamiento, atosigar, atracador, atracando, atracar, atraco, atraco, atrocidad, atroz, austero, avasallamiento, avasallar, bandolero, bastardo, batalla, batallador, batallando, batallar, bayoneta, belcebú, bélico, belicosidad, belicoso, beligerante, bellaco, bestialidad, blasfemar, blasfemia, boicot, boicotear, boicoteo, bomba, bombardear, bombardeo, bravucón, bribón, bronca, cacheteada, cachetear, cachiporra, calamidad, calumnia, calumniador, calumniando, calumniar, calumnioso, calvario, camorrista, canalla, carabina, castigar, castigo, cataclismo, catástrofe, caustico, celada, censura, censurar, cercenar, chantaje, chantajista, chiflado, chiflarse, cicatero, cínica, claudicar, cleptómano, coacción, coercer, cohecho, cohibir, cólera, colérico, coletazo, combate, combatiendo, combatiente, combatir, combatividad, combativo, complot, complotar, compulsión, condena, condenado, condenar, confabulación, confabular, confiscación, confiscar, conflagración, conflagración, conflicto, confrontación, confrontar, conjuración, conjurar, conminación, conspiración, conspirador, conspirar, constreñir, consternar, constreñir, contaminación, contaminado, contaminar, contender, contendiente, contestatario, contienda, contradecir, contradictorio, contraponer, 
contraproducente, contrincante, controversia, controvertir, contumacia, convicto, convulsión, convulsionar, corrompido, corrupción, corruptela, crimen, criminal, crispar, cruel, crueldad, cuartelazo, cuatrero, cuchillo, cuestionar, culpa, culpable, culpar, daga, damnificación, damnificado, damnificar, dañino, decapitar, defensivo, defraudado, defraudando, defraudar, defraudo, degollar, degollina, degradar, degradarse, dejadez, delincuente, demonio, denegar, denigración, denigrante, denigrar, denigrativo, denuncia, denunciar, deponer, deportación, deportar, depravado, depredar, derogación, derribar, derrotar, derruir, desacato, desacreditar, desacuerdo, desafiante, desafiar, desafuero, desagradable, desagraviar, desalentar, desalmado, desalojar, desalojo, desanimar, desaparecer, desapoderamiento, desaprobación, desaprobar, desaprueba, desasosiego, desastre, desatender, desatinar, desautorización, desautorizar, desavenencia, desazón, desbaratar, descabezado, descalabrar, descalificación, descalificar, descarado, descaro, descontento, descorazonar, descuartizar, descuidar, descuidero, descuido, desdecir, desdén, desdeñoso, desdichado, desencantado, desengañar, desequilibrarse, deserción, desertar, desertor, desesperación, desesperanzar, desestimar, desfalco, desfigurar, desgana, desgarrar, desgraciado, deshacer, deshacerse, deshecho, deshilachar, deshizo, deshonesto, deshonra, deshonrar, desidia, desigualdad, desilusión, desilusionar, desistimiento, desistir, desleal, deslealtad, desmantelado, desmantelar, desmembrar, desmentir, desmoralizar, desnucar, desobediencia, desobediente, desolación, desolar, desparecer, despecho, despectivo, despedazado, despedazar, despedido, despedir, despiadado, despidos, despojado, despojar, desposeer, déspota, despotismo, despotricar, despreciable, despreciado, despreciar, desprecio, desprestigiar, desquiciado, desquiciar, desquitar, desquitarse, desquite, destacamento, desterrado, desterrar, destierro, destituido, destituir, destripar, destrozado, destrozar, destrucción, destructivo, destructor, destruir, desunión, desunir, desvergonzado, desvergüenza, detención, detestable, detestar, detesto, detonación, detonador, detonar, detractar, desunión, devastación, devastar, diablo, diabólico, dictadura, difamación, difamador, difamar, difamatorio, difunto, dimisión, dimitir, díscolo, disconformidad, discordante, discordia, discrepancia, discrepante, discrepar, discriminación, discriminar, discusión, discutiendo, discutir, disensión, disentimiento, disentir, disgustado, disgustar, disgusto, disimulo, dislocación, dislocar, disolución, disoluto, disonancia, disputa, disputable, disputar, disputarse, distorsionar, disturbio, disuasivo, disuasorio, doblegarse, dolorido, dominación, embarullar, embate, embaucar, embestida, embestir, emboscada, emboscar, embrollar, embuste, embustero, embustir, emponzoñar, enajenar, enardecer, enardecido, encarcelamiento, encarcelar, encizañar, encolerizado, encolerizar, encrespar, enemigo, enemistad, enemistar, enemistarse, enervar, enfadado, enfadar, enfadarse, enfado, enfrentado, enfrentamiento, enfrentar, enfurecer, enfurecido, enfurecimiento, engañando, engañar, engaño, engañosa, engañoso, engatusar, engendro, engorro, engreimiento, enjuiciamiento, enjuiciar, enloquecer, enloquecido, enmascarar, enojado, enojar, enojo, ensañamiento, entorpecer, entristecer, envenenar, enviciar, envilecer, epidemia, escandalo, escaramuza, escarmentar, escarmiento, escarnio, escepticismo, escéptico, esclavitud, esclavizar, esclavo, escopeta, esfumarse, espada, espantar, espantarse, espinoso, espurio, estacazo, estafa, estafador, estafando, estafar, estafo, estallar, estallido, estigma, estigmatizar, estrago, estrangulación, estrangulamiento, estrangular, estremecer, estremecimiento, estremezco, estropeado, estropear, estuprar, evadir, evadirse, evasión, exabrupto, exasperación, exasperar, exclusión, exilio, expatriación, expatriado, expiación, explosión, explosionar, explosivo, explotar, expropiación, expulsar, expulsión, exterminar, exterminio, extinción, extirpar, extorsión, extralimitación, falsificación, falsificando, falsificar, fanfarrón, farfullar, farsa, farsante, fascismo, fastidiar, fastidio, fastidioso, fatal, fatídico, felonía, flagelar, flagelo, flecha, follón, forajido, forzado, forzar, fraccionar, fractura, fracturado, fracturar, fragmentar, francotirador, fratricida, fratricidio, fraude, frustración, frustrar, frustrarse, fuga, fugar, fugarse, funesto, furia, furioso, furtivo, fusil, fusilar, fusta, fusta, fustigar, gánster, garrocha, garrote, gatillo, golpe, golpeado, golpear, golpeo, golpismo, golpiza, granada, granuja, gresca, grilletes, grima, guerra, guerrear, guerrero, guerrilla, guerrillero, guillotinar, hastiado, hecatombe, herida, herido, herir, hipócrita, holocausto, homicida, homicidio, horrendo, horror, horrorizar, horrorizarse, hostigarían, hostigamiento, hostigar, hostil, hostilidad, hostilidades, hostilizar, huelga, huida, huir, humillante, humillar, hurtado, hurtando, hurtar, hurto, huyo, 
ignorado, ignorancia, ignorar, ilegal, ilegalidad, ilegitimo, ilícito, impedimento, impedir, impeler, impertinente, impiedad, implacable, implosión, impostor, improcedente, improperio, impúdico, impugnar, impurificar, imputación, imputar, inaceptable, incautación, accidentado, incinerar, incitación, incitar, incomodar, incomodidad, incompatibilidad, incompatible, inconmovible, inconsolable, incordiar, incordio, incredulidad, incrédulo, increpar, incriminación, incriminar, inculpación, inculpar, incumplimiento, indebido, indecente, indecoroso, indemnizar, indiferente, indignación, indignado, indigno, indisciplina, indocilidad, indolencia, indomable, ineptitud, inequidad, inescrupuloso, infamador, infamante, infamar, infame, infamia, infección, infectar, infecto, infestación, infestar, inficionar, ingrato, inhabilitación, inhabilitar, inhibición, inhibir, inhumano, injuria, injuriar, injurioso, injusticia, injustificado, injusto, inmerecido, inmolación, inmolado, inmolar, inmoral, inmundo, innoble, inoculación, inquina, insalubre, insano, insatisfecho, inseguro, insensible, insidia, insidioso, insolencia, insolente, instigación, instigador, instigar, insubordinación, insubordinado, insubordinarse, insultante, insultar, insulto, insumisión, insumiso, insurgente, insurrección, insurreccionarse, insurrecto, interferencia, interferir, intimidación, intimidar, intranquilidad, intranquilo, intransigencia, intransigente, intromisión, intrusión, inutilizar, invadido, invadir, invasión, iracundo, irascible, irracional, irracionalidad, irrazonable, irrespetuosidad, irreverencia, irrisorio, irritable, irritación, irritado, irritante, irritar, irrumpir, irrupción, jactancioso, jorobar, juzgar, laceración, lacerar, ladino, ladrón, lanceta, lapidar, lastimar, litigar, latigazos, látigo, leonino, letal, levantamiento, levantarse, levantisco, libertino, linchar, liquidación, liquidar, lisiar, litigante, litigar, litigio, llanto, lloriqueo, lucha, luchado, luchando, luchar, lucifer, luzbel, machacar, machete, madame, magnicida, magnicidio, magullado, magulladura, magullar, mal, malandrín, mal comportarse, maldad, maldecir, maldición, maldijo, maldito, maleante, maledicencia, malevolencia, malévolo, malhechor, malhumorado, malicia, malicioso, malignidad, maligno, malintencionado, malquerencia, malsano, maltratado, maltratar, maltrecho, malvado, malversación, malversado, malversando, malversar, malverso, marginar, masacrar, masacre, mascullar, matanza, matar, matón, mendacidad, mendaz, menoscabar, menospreciar, mentir, mentira, mentiroso, merodeo, metralleta, mezquino, milicia, militar, mintiendo, miserable, miseria, misil, mofa, mofar, molestar, molestia, molesto, molido, monstruo, monstruosa, monstruosidad, monstruoso, montaraz, mordacidad, mordaz, morder, mordida, mordió, mortal, mortandad, mortífero, mortificación, mortificado, mortificar, mosquetón, muerte, muertes, muerto, multa, munición, marginación, mutilar, navaja, nefasto, negligencia, nigromancia, nocivas, nocivo, obcecado, obligado, obligar, obliterar, obsceno, odiado, odiar, odio, ofender, ofendido, ofensa, ofensiva, ofuscación, ofuscado, ojeriza, ominoso, oponente, oponer, oponerse, oposición, opresión, oprimir, opuesto, ostentación, ostracismo, paliza, parricida, parricidio, patrulla, pécora, pegar, pego, pelea, peleón, pellizcar, pelotón, penado, penalizar, pendencia, pendenciero, penitencia, perjudicar, perjudicial, perjuicio, pernicioso, persecución, persecución, perseguir, persuadir, perturbación, perturbar, perversidad, perverso, pervertido, pervertir, pesadilla, pesadumbre, petulante, peyorativo, pillaje, pillar, piquete, pisotear, pistola, pistolero, pistolete, pleiteante, pleito, polémica, polemizar, polución, pólvora, ponzoña, ponzoñoso, porrazo, prejuicio, prescripción, presidiario, profanación, proscribir, proscripción, proscripto, protesta, protestar, provocador, proxeneta, pugna, pugnando, pugnar, pulverizar, punzar, puñal, puñalada, puñetazo, pútrido, quebrado, quebrantamiento, quebrantar, quebranto, quebrar, queja, quejar, quejarse, quejas, quejido, quejoso, querella, querellante, querellar, quiebra, quiebre, rabia, rabiar, rabieta, rapiñar, rapto, rastrero, ratero, reaccionario, rebelarse, rebelde, rebeldía, rebelión, recaída, recalcitrante, recelo, rechazar, rechazo, reclamar, reclamo, recluir, reclusión, recluso, recriminación, recriminar, refrenar, refriega, refunfuño, refutar, regañar, regaño, regicidio, rehuir, rehusar, rémora, rencor, rencoroso, renegar, renuncia, renunciar, repeler, reprobar, reprender, reprensión, represalia, represión, reprimenda, reprimir, reprobar, reprochar, reproche, repudiar, repudio, repugnancia, repugnante, repugnar, repulsión, repulsivo, resarcimiento, resarcir, resentido, resentimiento, resentir, resistencia, resistente, resistir, responsabilizar, resquemor, restringir, reticente, retorcido, retrogrado, revancha, reventado, reventar, revocación, revuelta, reyerta, rezongar, ridiculizar, ridículo, rifle, riñendo, rival, rivalidad, rivalizar, robado, robando, robar, robo, rufián, ruin, ruina, ruinoso, ruptura, sablista, sabotaje, sabotear, sacrificar, sacrificio, sádico, sadismo, salvajada, salvaje, sanguinario, saqueador, saqueo, satán, satanás, satánico, 
secuestrado, secuestrar, secuestro, sedición, sedicioso, segregación, segregar, sentencia, siniestro, sinvergüenza, soborno, socarronería, sofoco, sojuzgar, soliviantar, sollozo, someter, sopapear, soslayar, sospecha, sospechar, sospechoso, sublevación, sublevado, sublevarse, subversión, subversivo, subvertir, subyugar, sumisión, suspicacia, suspicaz, tabú, temerario, tergiversar, terrorismo, terrorista, tiranía, tiranizar, tirotear, tiroteo, tirria, torturado, torturar, tosigo, totalitarismo, toxico, tozudez, trágico, traición, traicionar, traicionero, traidor, traidores, tralla, trampa, trampear, tramposo, transgresión, transgresor, trastornado, trastornar, trastornarse, traumar, traumatismo, trifulca, triturar, trompazo, truhan, tumulto, turba, turbulento, ultimátum, ultrajar, ultraje, ultrajante, usurero, usurpado, usurpando, usurpar, usurpo, vandalismo, vapuleado, vapulear, vendetta, venganza, viciar, vicioso, victima, vil, vileza, vilipendio, villano, vindicta, violación, violar, violencia, violento, virulento, vividor, zaheridor, zaherir, zozobra, zurriago.

Violent words in Spanish: agresivo, combativo, provocador, violento, agresividad, belicosidad, combatividad, provocación, emboscada, celada, trampa, asechanza, artería, artimaña, emboscar, trampear, asechar, armas, armamento, armado, asaltar, atracar, robar, agredir, acometer, irrumpir, invadir, ataque, embate, irrupción, combate, lucha, agresión, golpear, golpe, sanguinario, choque, asalto, atropello, atentado, coletazo, bomba, explosivo, granada, munición, bala, brutalidad, bestialidad, ferocidad, crueldad, atrocidad, monstruosidad, irracionalidad, vandalismo, salvajada, grosería, masacre, matanza, mortandad, hecatombe, catástrofe, degollina, aplastar, triturar, reventar, destripar, moler, aplastamiento, mortal, mortífero, letal, fatídico, fatal, funesto, disparar, tirotear, ametrallar, despedir, expulsar, destituir, guerrilla, guerrillero, milicia, arma, pistola, revólver, pistolete, ametralladora, metralleta, pistolero, atracador, bandido, forajido, delincuente, gánster, terrorista, asesino, matar, asesinar, ahorcar, ahogar, decapitar, desnucar, degollar, fusilar, guillotinar, asfixiar, electrocutar, envenenar, linchar, asesinato, crimen, homicidio, delito, muerte, parricidio, fratricidio, magnicidio, regicidio, criminal, homicida, monstruo, engendro, deforme, monstruosa, rebelarse, incitar, sublevarse, insubordinarse, levantarse, alzarse, amotinarse, insurreccionarse, rebelión, levantamiento, revuelta, alzamiento, revolución, subversión, conspiración, conjuración, sedición, insurrección, motín, acuchillar, apuñalar, lesionar, violencia, exabrupto, coacción, profanación, furia, ensañamiento, violación, implacable, furioso, guerrero, soldado, militar, látigo, azote, fusta, tralla, vergajo, flagelo, zurriago, latigazos, azotando, litigar, azotar, fustigar, flagelar. 


\section{Annex A2}

Table A2.1

Augmented Dickey-Fuller test for unit root

\begin{tabular}{lcccc}
\hline Variable & Number of lags & $T$-Statistic & $1 \%$ critical value & $5 \%$ critical value \\
\hline Metal prices index & $\operatorname{lags}(2)$ & -2.106 & -3.587 & -2.933 \\
\hline D.Metal prices index & $\operatorname{lags}(1)$ & -4.379 & -3.587 & -2.933 \\
\hline Factor No. 1-Standardized Conflict Index & $\operatorname{lags}(3)$ & -1.927 & -3.628 & -2.95 \\
\hline D.Factor No. 1 - Standardized Conflict Index & $\operatorname{lags}(4)$ & -4.407 & -3.655 & -2.961 \\
\hline Predicted error & $\operatorname{lags}(0)$ & -4.613 & -4.124 & -3.461 \\
\hline Predicted error & $\operatorname{lags}(1)$ & -2.707 & -4.124 & -3.461 \\
\hline Predicted error & $\operatorname{lags}(2)$ & -1.534 & -4.124 & -3.461 \\
\hline Predicted error & $\operatorname{lags}(3)$ & -1.231 & -4.124 & -3.461 \\
\hline
\end{tabular}

Source: Prepared by the authors.

Table A2.2

Vector autoregression results: factor No. 1 - standardized conflict index and metal prices index

\begin{tabular}{|c|c|c|c|c|c|c|}
\hline \multicolumn{7}{|c|}{ Vector autoregression } \\
\hline Sample: Q3 2003 - Q4 2015, but with a gap & \multicolumn{6}{|c|}{ No. of obs $=47$} \\
\hline Log likelihood = -216.7898 & \multicolumn{6}{|c|}{$\mathrm{AIC}=9.480418$} \\
\hline $\mathrm{FPE}=44.92575$ & \multicolumn{6}{|c|}{$\mathrm{HQIC}=9.569297$} \\
\hline Det (Sigma_ml) = 34.7905 & \multicolumn{6}{|c|}{$\mathrm{SBIC}=9.716607$} \\
\hline Equation & Parms & RMSE & R-sq & $\mathrm{Chi}^{2}$ & $\mathrm{P}>\mathrm{chi}^{2}$ & \\
\hline D_metal_prices_index & 3 & 14.5725 & 0.0737 & 3.737807 & 0.1543 & \\
\hline \multirow[t]{2}{*}{ D_f1_sc } & 3 & 0.442755 & 0.2788 & 18.17191 & 0.0001 & \\
\hline & Coef. & Std. Err. & z & $P>z$ & {$[95 \% \mathrm{C}$} & Interval] \\
\hline \multicolumn{7}{|l|}{ D_metal_prices_index } \\
\hline \multicolumn{7}{|l|}{ metal_prices_index } \\
\hline LD. & 0.266852 & 0.145429 & 1.83 & 0.067 & -0.01818 & 0.551888 \\
\hline \multicolumn{7}{|l|}{ f1_sc } \\
\hline LD. & -4.57089 & 4.260941 & -1.07 & 0.283 & -12.9222 & 3.780397 \\
\hline _cons & 2.260713 & 2.096179 & 1.08 & 0.281 & -1.84772 & 6.369148 \\
\hline \multicolumn{7}{|l|}{ D_f1_sc } \\
\hline \multicolumn{7}{|l|}{ metal_prices_index } \\
\hline LD. & 0.008484 & 0.004419 & 1.92 & 0.055 & -0.00018 & 0.017144 \\
\hline \multicolumn{7}{|l|}{ f1_sc } \\
\hline LD. & -0.54093 & 0.12946 & -4.18 & 0.000 & -0.79466 & -0.28719 \\
\hline _cons & -0.0027 & 0.063688 & -0.04 & 0.966 & -0.12752 & 0.122131 \\
\hline
\end{tabular}

Source: Prepared by the authors. 
Table A2.3

Year and country fixed-effects regressions of the standardized violent conflict news index

\begin{tabular}{|c|c|c|c|c|c|c|}
\hline Variables & $\begin{array}{c}1 \\
\text { In } \\
\text { (standardized conflict } \\
\text { news (scn) index) }\end{array}$ & $\begin{array}{c}2 \\
\text { In } \\
\left(s v \_ \text {index }\right)\end{array}$ & $\begin{array}{c}3 \\
\text { In } \\
\left(s v \_ \text {index }\right)\end{array}$ & $\begin{array}{c}4 \\
\text { In } \\
\left(s v \_ \text {index }\right)\end{array}$ & $\begin{array}{c}5 \\
\text { In } \\
\left(s v_{-} \text {index }\right)\end{array}$ & $\begin{array}{c}6 \\
\text { In } \\
\left(s v \_ \text {index) }\right.\end{array}$ \\
\hline \multirow[t]{2}{*}{ In (mineral rents \% of GDP) } & 0.0344 & 0.0393 & 0.0866 & & & \\
\hline & $(0.104)$ & $(0.107)$ & $(0.106)$ & & & \\
\hline \multirow[t]{2}{*}{ In (metal_prices_index) } & & & & -0.0108 & 0.00591 & 0.0232 \\
\hline & & & & $(0.103)$ & $(0.129)$ & $(0.103)$ \\
\hline \multirow[t]{2}{*}{$\begin{array}{l}\text { In (per capita GDP - constant } 2010 \\
\text { United States dollars) }\end{array}$} & & -0.130 & & & -0.101 & \\
\hline & & $(0.470)$ & & & $(0.458)$ & \\
\hline \multirow[t]{2}{*}{$\begin{array}{l}\text { First difference_In (per capita GDP - } \\
\text { constant } 2010 \text { United States dollars) }\end{array}$} & & & $-4.425^{\star}$ & & & -3.809 \\
\hline & & & (2.612) & & & (2.488) \\
\hline \multirow[t]{2}{*}{ Constant } & $-1.215^{\star \star \star}$ & 0.0467 & $-1.120^{\star \star \star}$ & $-1.173^{\star \star}$ & -0.260 & $-1.235^{\star \star}$ \\
\hline & $(0.0985)$ & $(4.572)$ & $(0.111)$ & $(0.496)$ & $(4.169)$ & $(0.489)$ \\
\hline Observations & 52 & 52 & 52 & 52 & 52 & 52 \\
\hline R-squared & 0.382 & 0.383 & 0.430 & 0.380 & 0.381 & 0.419 \\
\hline Country and year effects & Yes & Yes & Yes & Yes & Yes & Yes \\
\hline Number of countries & 4 & 4 & 4 & 4 & 4 & 4 \\
\hline
\end{tabular}

Source: Prepared by the authors.

Note: Coefficient significant at ${ }^{\star \star \star} p<0.01,{ }^{\star \star} p<0.05,{ }^{*} p<0.1$. Robust standard errors shown in parentheses. 